\title{
RESEARCH PLAN TO DETERMINE TIMING, LOCATION, MAGNITUDE AND CAUSE OF MORTALITY FOR WILD \& HATCHERY SPRING/SUMMER CHINOOK SALMON SMOLTS ABOVE LOWER GRANITE DAM
}

\section{FINAL REPORT}

Prepared by:

Lower Granite Migration Study Steering Committee

Prepared for:

U.S. Department of Energy

Bonneville Power Administration

Division of Fish and Wildlife

P.O. Box 3621

Portland, OR 97283-362 1

Project Number 9 1-O 17

Contract Number DE-A179-92BP6 1176

OCTOBER 1993 
EXECUTIVE SUMMARY $\ldots \ldots \ldots \ldots \ldots \ldots \ldots \ldots \ldots \ldots \ldots \ldots \ldots \ldots \ldots$

PURPOSE OF PROPOSED RESEARCH $\ldots \ldots \ldots \ldots \ldots \ldots \ldots \ldots \ldots \ldots \ldots$

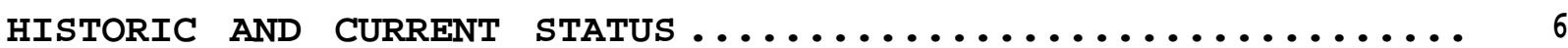

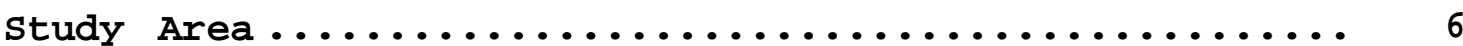

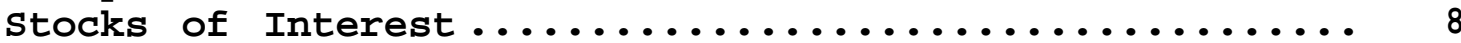

Ongoing Management and Research ................ 10

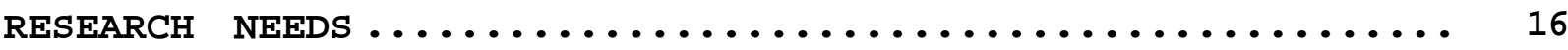

PROGRAM STRUCTURE AND SCHEDULE $\ldots \ldots \ldots \ldots \ldots \ldots \ldots \ldots \ldots \ldots$

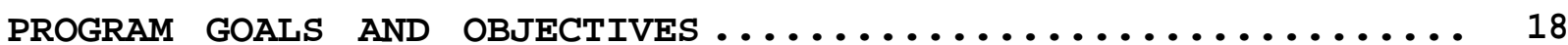

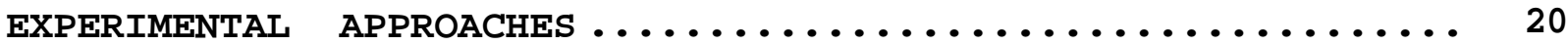

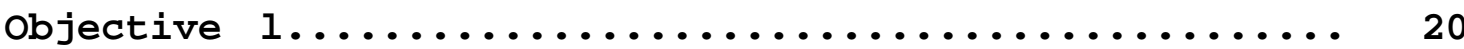

Background ........................ 20

Potential Methods of Evaluation............. 22

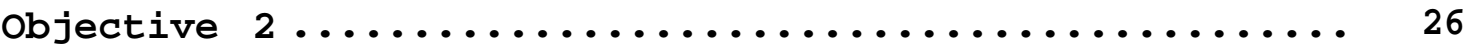

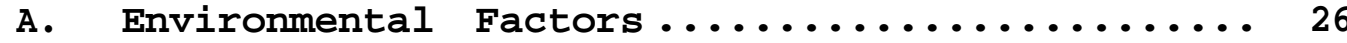

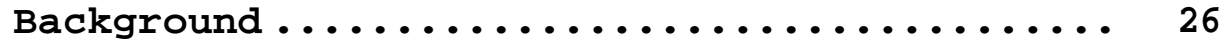

Potential Methods of Evaluation.......... 27

B. Smolt Condition and Disease ............ 31

Background ..................... 31

Potential Methods of Evaluation.......... 34

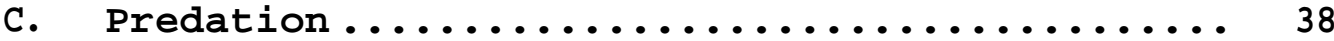

Background .................... 38

Potential Methods of Evaluation ..........43

D. Food Availability .................. 45

Background ..................... 45

Potential Methods of Evaluation ..........4 47

E. Wild and Hatchery Interactions ........... 49

Background ..................... 49

Potential Methods of Evaluation .......... 50

INTEGRATION WITH ONGOING RESEARCH AND MANAGEMENT ACTIVITIES. 53

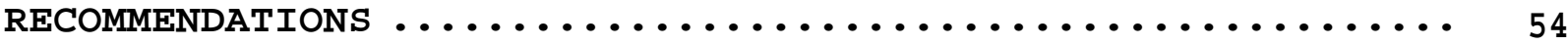

Research Priorities ...................... 54

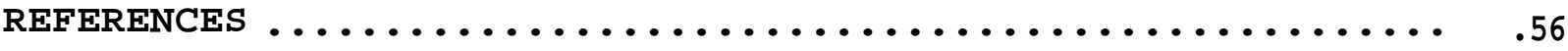

IIST OF CONTRIBUTORS ...................... 68 
APPENDIX...............................69

Comment Letters............................. $\sigma^{\prime}$ 


\section{EXECUTIVE SUMMARY}

From 1966 to 1968, Raymond (1979) estimated an average survival rate of $89 \%$ for yearling chinook salmon (Oncorhvnchus tshawytscha) migrating from trap sites on the Salmon River to Ice Harbor Dam, which was then the uppermost dam on the Snake River. During the 1970s, the estimated survival rate declined as the proportion of hatchery fish increased and additional dams were constructed.

Recent survival indices for yearling chinook salmon smolts in the Snake River Basin indicate that substantial mortalities are occurring en route to Lower Granite Dam, now the uppermost dam on the Snake River (Giorgi 1991). Detection rates for wild and hatchery PIT-tagged smolts at Lower Granite Dam have been much lower than expected. However, for wild fish, there is considerable uncertainty whether overwinter mortality or smolt loss during migration is the primary cause for low survival. In 1992, spring/summer chinook salmon in the Snake River Basin were listed as threatened species under the Endangered Species Act. Efforts to rebuild these populations will have a better chance of success after the causes of mortality are identified and addressed. Information on the migrational characteristics and survival of wild fish are especially needed.

The goal of this initial planning phase is to develop a research plan to outline potential investigations that will determine the timing, location, magnitude, and cause of smolt mortality above Lower Granite Dam. Experimental approaches 
suggested in this research plan should not be considered allinclusive or prescriptive. Details and logistics for each study will be specifically addressed in research proposals submitted by individual investigators. Results from this research should provide direction for improving the survival of wild and hatchery chinook salmon produced above Lower Granite Dam and possibly elsewhere in the Columbia River Basin.

The objectives of these studies will be to 1) determine survival rates and migrational characteristics of yearling chinook salmon smolts from natural tributary production areas and hatchery release sites to Lower Granite Dam, and 2) identify factors affecting mortality and migrational characteristics of wild and hatchery yearling chinook salmon smolts above Lower Granite Dam. Possible factors to be investigated include environmental influences, smolt condition and disease, predation, food availability, and wild and hatchery smolt interactions.

Beginning with the 1993 migration, all hatchery yearling chinook salmon will be marked prior to release, providing the opportunity to distinguish between wild and hatchery smolts downstream. We recommend that pilot studies begin in 1993 to develop survival estimation methods for wild and hatchery smolts. This will require one or more new trap sites in the Salmon River and/or seining in the reservoir to obtain sufficient numbers of wild smolts for PIT tagging. These studies could be integrated with the Smolt Monitoring Program. 
At a minimum, this effort will produce improved travel-time estimates for wild and hatchery smolts along the migration corridor. This research plan also identifies the need to determine distribution patterns and movement of smolts in Lower Granite Reservoir, especially in the forebay. Research should begin where potential factors causing mortality can be integrated easily with survival estimation studies or other ongoing research. 
PURPOSE OF PROPOSED RESEARCH

Runs of spring/summer chinook salmon Oncorhvnchus tshawvtscha, in the Snake River Basin have been severely depressed for the past few decades. There are three main races of chinook salmon: spring, summer, and fall. These runs are categorized primarily on the basis of adult migration timing. The Lower Granite Migration Study (LGMS) will focus on spring and summer races, which are considered a single species by the National Marine Fisheries Service (NMFS) and referred to as chinook salmon or yearling chinook salmon in this research plan (NMFS 1991). Yearling or "stream type" chinook salmon (Healy 1983) migrate to the ocean in their second year. Fall or "ocean type" chinook salmon, which migrate to the ocean in their first year, are being investigated in the Snake River by the United States Fish and Wildlife Service (USFWS) and others (Rondorf et al. 1991).

In recent years, wild spring/summer chinook salmon populations have declined to a level prompting listing as a threatened species under the Endangered Species Act (ESA) (NMFS 1991). Despite increased smolt releases (Table 1), substantial improvements in smolt bypass collection and transportation facilities, and use of the Water Budget and spill, adult returns of chinook salmon to the Snake River Basin remain depressed.

From 1966 to 1968, Raymond (1979) estimated an average survival rate of $89 \%$ for yearling chinook salmon migrating from trap sites on the Salmon River to Ice Harbor Dam, then the 
Table 1.--Number (in thousands) of yearling spring/summer chinook salmon and steelhead (Oncorhvnchus mykiss) released from hatcheries into the Snake River, 1982-1991. Data from Fish Passage Center Annual Reports.

\begin{tabular}{lrrr}
\hline Year & $\begin{array}{l}\text { Chinook } \\
\text { salmon }\end{array}$ & Steelhead & Total \\
\hline 1982 & 2,805 & 5,300 & 8,105 \\
1983 & 5,890 & 3,475 & 9,365 \\
1984 & 8,318 & 6,215 & 14,533 \\
1985 & 8,608 & 5,939 & 14,547 \\
1986 & 6,495 & 7,587 & 14,082 \\
1987 & 11,721 & 7,806 & 19,527 \\
1988 & 11,572 & 11,388 & 22,960 \\
1989 & 11,628 & 9,009 & 20,637 \\
1990 & 12,633 & 11,116 & 23,749 \\
1991 & 9,742 & 11,331 & 21,073 \\
& & & \\
\hline
\end{tabular}


uppermost dam on the Snake River (Table 2). From 1970 to 1975, Raymond (1979) estimated an average survival rate of $68 \%$ from the Salmon River to the uppermost dam (Little Goose Dam from 1970 to 1974 and Lower Granite Dam in 1975). Raymond's earlier estimates were predominately for wild fish, while his later estimates were based on 43 to $75 \%$ hatchery fish.

Raymond (1979, 1988) attributed poor smolt-to-adult survival for Snake River chinook salmon stocks primarily to mortality associated with smolt migration through the eight dams and reservoirs between production areas and the ocean. However, recent information indicates that significant mortality of hatchery and wild smolts also occurs between the release sites or tributary production areas and Lower Granite Dam (LGR), the uppermost dam on the Snake River. General survival indices (detection proportions expanded by constant fish guidance efficiency estimates) for passive integrated transponder (PIT) tagged yearling chinook salmon in the Snake River Basin indicate that substantial losses occur en route to LGR (Giorgi 1991). From 1989 to 1991, an average of only 7 and 30\% of PIT-tagged yearling chinook salmon released from Sawtooth and Dworshak National Fish Hatcheries (NFH) were detected at LGR--a general survival rate of 14 and 56\%, respectively (Table 2).

Wild chinook salmon parr PIT-tagged in tributaries of the Salmon, Imnaha, and Grande Ronde Rivers have also been detected at rates lower than expected (Matthews et al. 1990, 1992). Between 1989 and 1991, detection rates at LGR averaged less 
Table 2. --Survival estimates for yearling chinook salmon migrating in the Snake River Basin to the uppermost dam; Ice Harbor in 1968, Little Goose in 1970, and Lower Granite in 1975.

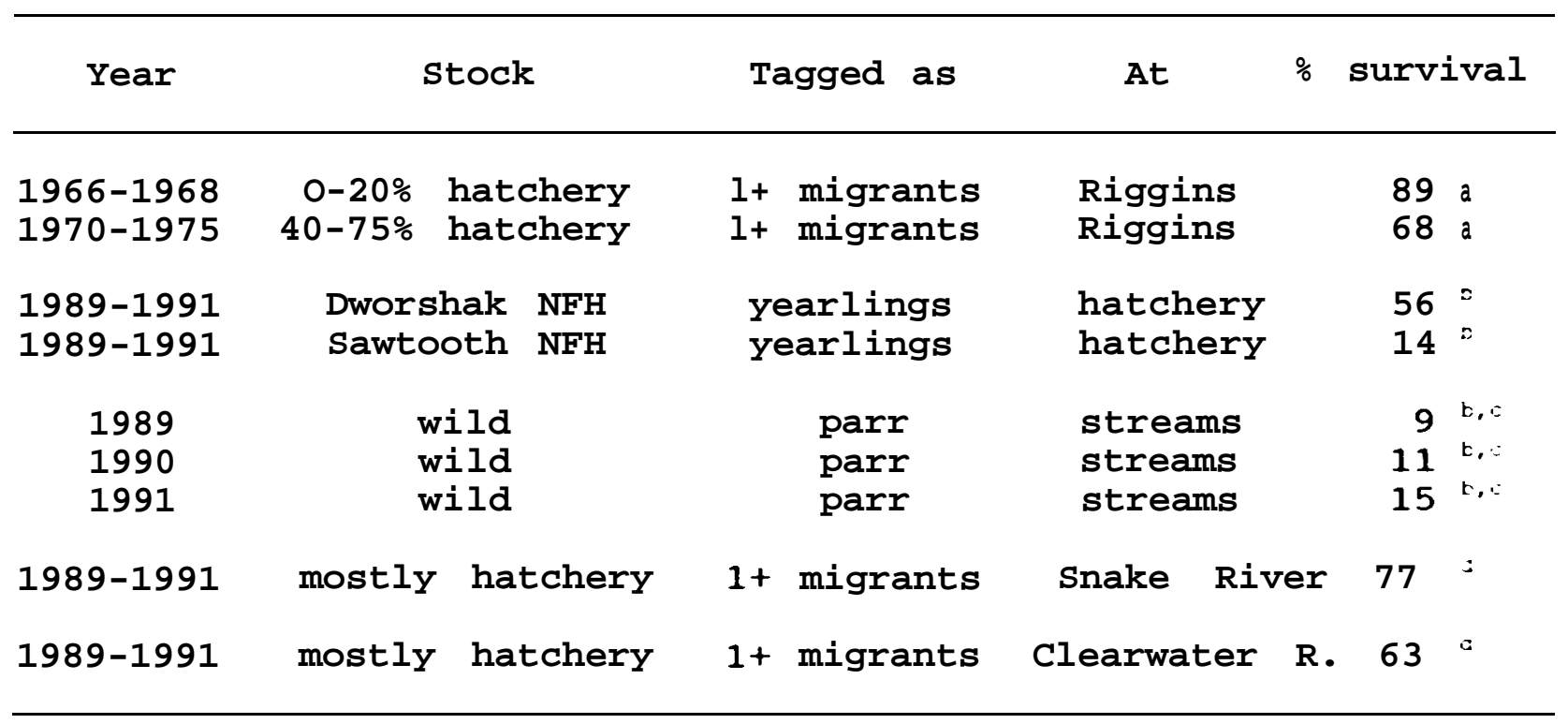

Gatewell catches expanded by collection efficiency estimates for yearling migrants from the Riggins trap (Raymond 1979). PIT-tag detections at Lower Granite Dam expanded by a constant fish guiding efficiency estimate of 53\% (Giorgi 1991).

Mean survival for all streams combined from Matthews et al. (1990, 1992) using the estimation method of footnote $b$. Mean survival from the Snake or Clearwater River traps (Buettner and Nelson 1990, 1991) using estimation method of footnote $b$. 
than 5 to 8\% each year, indicating a general survival rate of 9 to $15 \%$. There is considerable uncertainty whether overwinter mortality or smolt loss during migration was the primary cause for low parr-to-smolt survival (Table 2).

From 1989 to 1991, a mix of hatchery and wild PIT-tagged yearling migrants had an average general survival rate from the Snake and Clearwater River traps of 77 and $63 \%$, respectively (Table 2) (Buettner and Nelson 1990, 1991). The discrepancy between past and present survival estimates may be related to the influence of chinook salmon hatchery programs. Estimates from the 1960s were for stocks with a higher proportion of wild fish, while current estimates are primarily for hatchery stocks (Table 2). Today, greater than $90 \%$ of yearling chinook salmon arriving at LGR come from hatcheries (Miller et al. 1990).

Poor survival of hatchery stocks could be attributable to inferior smolt quality, such as high levels of bacterial kidney disease (BKD), incomplete smolt development, maladaptive behaviors, or a combination of these factors. Possibly, hatchery fish interact with wild fish in such a way as to decrease the survival of both. Moreover, the migration corridor has changed since the addition of LGR, creating conditions that might contribute to these losses. Increased predator numbers, increased competition for food due to increased smolt numbers, combined with extended residence times, are factors which might contribute to poor smolt survival within LGR Reservoir. 
Although these survival estimates may lack precision, they do indicate that significant mortality is occurring en route to LGR and may be a significant factor limiting the production of spring/summer chinook salmon in the Snake River Basin. The timing, location, magnitude, and cause(s) of mortality must be determined in order to develop recommendations to improve the survival of smolts migrating through LGR Reservoir.

\section{HISTORIC AND CURRENT STATUS}

Several recent comprehensive compilations of information on the status and life history of chinook salmon in the Snake River Basin are available (Chapman et al. 1991; Matthews and Waples 1991; COE 1992). Therefore, only information pertinent to this research plan is summarized.

\section{Study Area}

The LGMS area will extend from LGR on the Snake River (River kilometer, RKM 696) upstream to tributary production areas and hatcheries (Figure 1). LGR is the first hydroelectric facility that smolts encounter on their migration to the Pacific Ocean. The primary tributaries contributing yearling chinook salmon are the Salmon and Clearwater Rivers in Idaho, and the Grande Ronde and Imnaha Rivers in northeastern Oregon. Although the LGMS will be limited to areas upstream from LGR, the information gained may have application throughout the Columbia River Basin. 


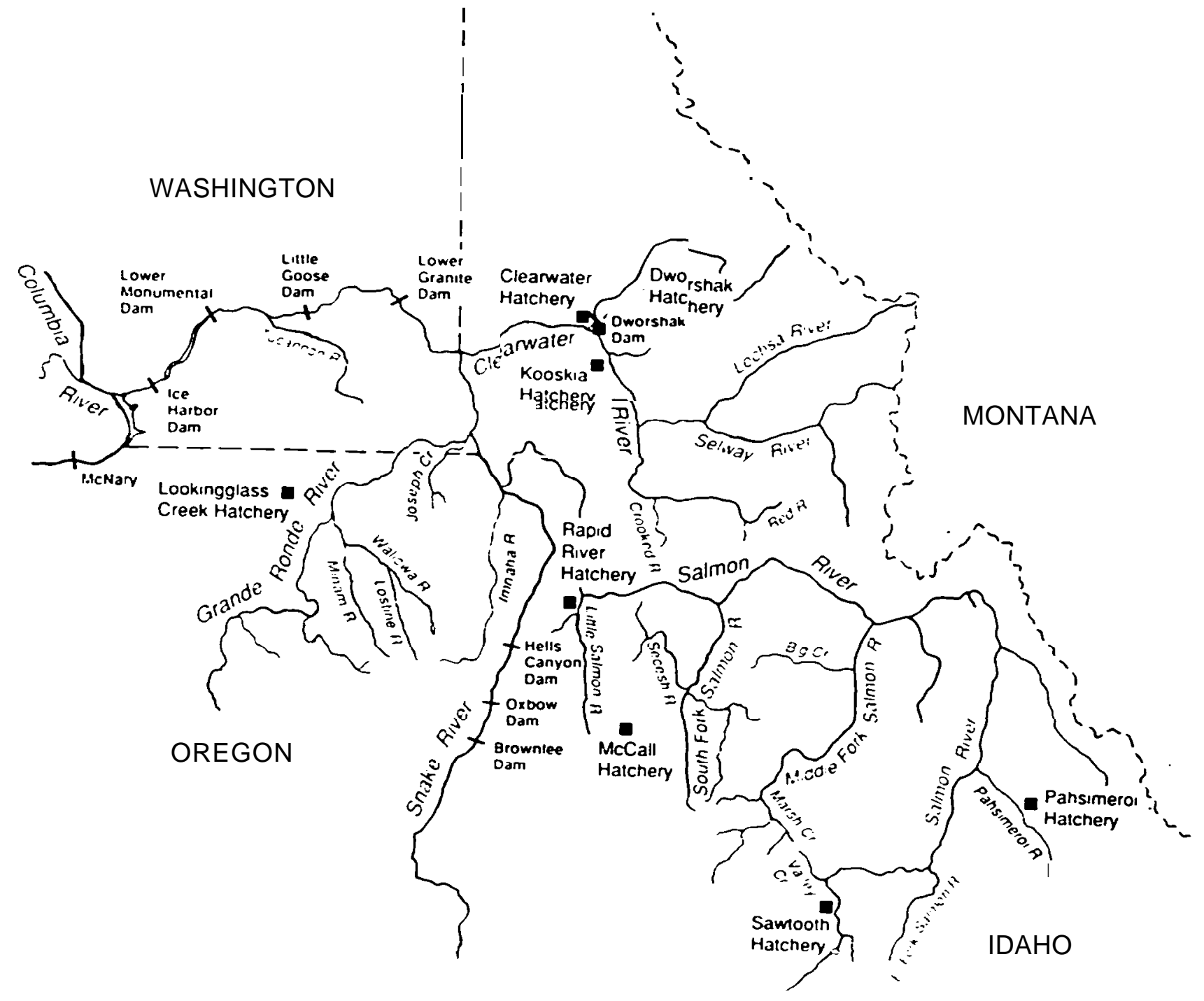

Figure 1.--Lower Granite migration study area showing locations of dams and yearling chinook salmon hatcheries. 
Stocks of Interest

Historically, summer chinook salmon have spawned in the lower portions of tributaries, while spring chinook salmon spawned in the upper portions (Chapman et al. 1991). Spring/summer chinook salmon migrate from their natal streams as subyearlings in the fall or as yearlings the following spring. Subyearlings that migrate in the fall probably overwinter in lower tributary reaches until the following spring (Raymond 1979; Kiefer and Forster 1990). Summer chinook salmon smolts tend to migrate earlier in the spring than spring chinook salmon smolts, possibly because of the earlier warming of lower-elevation streams (Raymond 1979; Chapman et al. 1991). Their migration periods overlap at LGR so that no distinction between the two races is practical unless fish are tagged prior to migrating.

In recent years, hatchery production has accounted for greater than $90 \%$ of the yearling chinook salmon smolts arriving at LGR (Miller et al. 1990). There are currently seven chinook salmon hatcheries in Idaho and one in Oregon above LGR. Total current production from these facilities is about 12 million yearling chinook salmon smolts (Table 3). A similar number of hatchery steelhead, $\underline{0}$. mykiss, are produced in the Snake River Basin. Hatchery production has increased steadily during the 1980s (Table 1) and is expected to continue to increase in future years with additional production from the clearwater Hatchery and the proposed Nez Perce Hatchery (Bowles and Leitzinger 1991). 
Table 3.--Spring/summer chinook salmon hatchery production above Lower Granite Dam (Chapman et al. 1991).

\begin{tabular}{lllll}
\hline & Race & Production & First brood & Agency \\
\hline Rapid River & Spring & $3,000,000$ & 1964 & \\
Kooskia & Spring & 800,000 & 1966 & IDFG \\
Sawtooth & Spring & $2,235,000$ & 1978 & USFWS \\
Dworshak & Spring & $1,050,000$ & 1981 & USFWS \\
Lookingglass & Spring & $1,390,000$ & 1981 & USFWS \\
Clearwater & Spring & $1,369,500$ & 1991 & ODFW \\
McCall & Summer & $1,000,000$ & 1978 & IDFG \\
Pahsimeroi & Summer & $1,000,000$ & 1987 & IDFG \\
& & & & IDFG \\
\hline
\end{tabular}


Although it is recognized that significant mortality of spring/summer chinook salmon may occur during various life stages (i.e., egg-to-parr, parr-to-smolt, smolt mortality downstream from LGR, smolt-to-adult), the LGMS will focus only on factors affecting the survival of yearling chinook salmon from rearing or release areas to LGR. Narrowing the focus of the research plan to this life stage should improve the quality of study results.

Ongoing Management and Research

There are a variety of current chinook salmon management and research activities in the Snake River Basin that could provide information or affect the conduct of LGMS projects. Every effort will be made to integrate LGMS research with these ongoing activities to avoid duplication of effort while providing sufficient information to these programs (see page 53).

Endangered Species Act

Spring/summer chinook salmon were recently listed as a threatened species under the ESA (NMFS 1991). The take, or handling, harassing, and/or sacrificing of listed species, is monitored by the NMFS and will be restricted. The LGMS research plan will be reviewed by the Snake River ESA Recovery Team to determine whether it provides sufficient information to justify the necessary handling of listed stocks.

Smolt Monitoring Program

The Water Budget, managed by the Fish Passage Center (FPC), is a volume of stored water available for use between 15 April and 15 June to enhance the downstream migration of salmonids (FPC 
1991, 1992). The FPC collects data on smolt passage at Snake and Columbia River dams through the Smolt Monitoring Program (SMP) to guide use of the Water Budget. To assess travel time, the FPC marks groups of fish from selected hatcheries and traps (including wild fish) with PIT tags or freeze brands each year in the Snake River Basin. Many of the research needs identified in this research plan could be conducted by or integrated with the Smolt Monitoring Program.

Drawdown Experiments

Drawing down LGR and other Snake and Columbia River reservoirs has been proposed as a means to increase salmonid migration speed and presumably survival (COE 1992). During March 1992, LGR Reservoir was lowered to test the physical effects of drawdown. Future drawdown experiments involving the LGR Reservoir could affect the LGMS, because the LGR juvenile bypass and PIT-tag detection system will become inoperable during drawdown. These circumstances would make it difficult to monitor fish passing LGR.

Hatchery Release Timing

Hatchery releases of yearling chinook salmon are usually made from mid-March to mid-April, often before natural migration occurs. One reason early releases are used is to avoid migrational overlap and interaction with hatchery steelhead in the collection facility at LGR. However, release dates influence migrational timing and could affect smolt survival to LGR. 
Lower Snake River Compensation Plan

This plan mitigates salmonid losses due to construction of the four Snake River dams. Several chinook salmon hatcheries upstream from LGR operate under this plan, which also supports research to improve smolt survival. Marked groups of chinook salmon used for this research and evaluation may be useful to the LGMS .

Transportation Program

The juvenile salmonid transportation program collects migrating smolts at LGR, Little Goose, and McNary Dams and transports them by barge or truck to release sites below Bonneville Dam. The decision to transport or return smolts to the river is based on flow projections (Ceballos et al. 1991, 1992). Transport of PIT-tagged smolts from LGR could affect survival estimates derived by certain methods.

Smolt Monitoring at the Head of Lower Granite Reservoir

As part of the Smolt Monitoring Program, the Idaho Department of Fish and Game (IDFG) operates juvenile migrant traps at the confluence of the Clearwater and Snake Rivers at Lewiston, Idaho, to monitor the salmonid migration (Buettner and Nelson 1990, 1991). A sample of captured smolts (a mix of hatchery and wild) are PIT-tagged and released to evaluate migrational timing and detection at downstream sites, including LGR. During the 1993 migration, all hatchery chinook salmon will be marked prior to release so that separate estimates of travel time and detection from traps to downstream sites can be obtained for wild and 
hatchery chinook salmon. This will provide information on migrational timing and survival that will be useful to the LGMS. Expanding this effort could provide some of the information on mortalities needed to achieve LGMS goals.

Assessment of Smolt Condition for Travel-Time Analysis

As part of the Smolt Monitoring Program, the USFWS monitors the physiological condition of smolts at release from hatcheries and downstream at the IDFG traps and Snake River dams (Beeman et al. 1990, 1991). This research has shown that river flow and smolt development are important factors influencing smolt travel time through LGR Reservoir. Continuation and expansion of this research will provide pertinent information to the LGMS. Supplementation Studies

Idaho Supplementation Studies began in 1992 with 19 treatment and 11 control streams in both the Salmon River and the Clearwater River drainage (Bowles and Leitzinger 1991). Supplementation experiments consist of outplanting chinook salmon at various life stages and comparing populations in treatment with those in control streams. Researchers freeze brand and PIT tag chinook salmon at various life stages over a wide geographic area. Migrant traps located in tributaries are used to evaluate migrational timing and survival. The LGMS will use these trapped and marked fish if possible, and provide feedback on smolt survival to the supplementation studies. 


\section{Wild Parr Marking Studies}

NMFS began PIT tagging wild chinook salmon parr in Idaho and Oregon tributaries in 1988 to determine if sufficient numbers could be captured, marked, and recovered at LGR to evaluate transportation of wild stocks (Matthews et al. 1990; Achord et al. 1992; Matthews et al. 1992). In 1991, the Bonneville Power Administration (BPA) began funding this project to evaluate migrational timing and survival of wild stocks. Survival of wild chinook salmon to LGR has been much lower than expected; however, there is considerable uncertainty whether it is overwinter mortality or losses incurred during migration that accounts for this poor survival. The LGMS will address survival questions for wild smolts migrating from upstream tributaries to LGR.

IDFG also PIT tags wild chinook salmon parr as part of its Idaho Habitat and Natural Production Monitoring Program (Kiefer and Forster 1990), as does the Oregon Department of Fish and Wildlife (ODFW) as part of its Smolt Monitoring Program.

\section{Fall Chinook Salmon Studies}

The USFWS and others are currently conducting studies on fall chinook salmon above LGR (Rondorf et al. 1991). Some of the techniques and equipment used in these studies could be used for yearling chinook salmon research (e.g., hydroacoustic equipment). Additionally, information on yearling chinook salmon, gathered while conducting fall chinook salmon research, could be utilized by the LGMS. 
Predator/Prey Studies

Several organizations are currently conducting predation research in LGR Reservoir. The USFWS and ODFW periodically index predator populations in the reservoir (Shively et al. 1991; Ward et al. 1993), while Columbia River Inter-tribal Fish Commission (CRITFC), ODFW, and Washington Department of Wildlife (WDW) are currently conducting predator control programs (Beaty et al. 1993; Burley et al. 1993). Information from predator indexing may be useful to the LGMS, and any LGMS research on predation will be coordinated with these efforts.

BKD Segregation and Rearing-Density Studies

As part of the recent BKD segregation and rearing-density studies conducted at Dworshak and Sawtooth NFHs, large numbers of PIT-tagged smolts have been released (Elliot and Pascho 1991, 1992). If this work continues, segregation and rearing-density study fish could be used for LGMS survival estimates.

Smolt Quality Assessment Studies

This research is aimed at identifying the relation between smolt development and adult returns, and factors that may be controlled through fish husbandry techniques. The results to date indicate that yearling chinook salmon from Dworshak NFH undergo little smolt development prior to release (zaugg et al. 1991). This lack of development could influence their travel t i m e. 
Dredge Spoil Disposal Studies

Dredge disposal studies in LGR Reservoir conducted by the University of Idaho (U of I) have examined habitat use, seasonal abundance, and food habits of salmonids and their predators, and invertebrate abundance in portions of LGR Reservoir (Bennett and Shrier 1986; Bennett et al. 1988a,b, 1990, 1991). Hydroacoustic surveys conducted by Biosonics have examined abundance and distribution of fish in LGR Reservoir (Thorne et al. 1992). The LGMS would utilize the results of this research as background information for several areas of study.

\section{RESEARCH NEEDS}

Although considerable research has been conducted on yearling chinook salmon upstream from LGR, several important unanswered questions remain. For example, why are detections of marked hatchery and wild yearling chinook salmon smolts at LGR lower than expected? Are low detection rates related to variable fish guidance efficiency (FGE) and unidentified tagging effects or, in the case of wild PIT-tagged fish, overwinter mortality? Separate estimates of survival for wild and hatchery smolts are necessary to determine if mortality between release and recovery at LGR is excessive. If survival rates are unacceptably low for wild fish, hatchery fish, or both, then determining when, where, and why mortality occurs during migration is necessary to alleviate causes. 
Better estimates of travel time for wild chinook salmon smolts are also needed. Existing travel-time estimates, based predominantly on hatchery smolts, are partially dependent on rearing history and the physiological development of fish at release time. Travel time is often used as an indicator of survival because it is more easily obtained than actual survival rates. Determining the distribution of wild and hatchery smolts within the reservoir is also necessary, since travel-time estimates between release and recapture locations do not describe the actual migration patterns. For example, some biologists speculate that yearling chinook salmon migrate through IGR Reservoir and then congregate or stage in the LGR forebay, where they may incur high mortality. This hypothesis should be explored. Developing improved smolt traps for use in the Salmon and Snake Rivers and in LGR Reservoir would help address these questions.

\section{PROGRAM STRUCTURE AND SCHEDULE}

This research plan is the product of Phase I of a study designed to determine the timing, location, magnitude, and cause of mortality of wild and hatchery chinook salmon smolts above LGR. This comprehensive research plan was developed during Phase I to facilitate coordinated efforts in addressing survival concerns in the Snake River Basin. Phase II will consist of coordinated research projects to address the research needs identified in this research plan. 
After regional review of this research plan (fall 1992), individual agencies and other interested parties will develop specific project proposals for the LGMS. Proposals will be coordinated by the LGMS Steering Committee, reviewed through the Implementation Planning Process, and funded by BPA. Program management will be similar to the white sturgeon and predator/prey studies currently funded by the BPA. The LGMS Steering Committee will continue to function in a technical advisory role during Phase II.

This research plan was prepared by a Steering Committee consisting of individuals representing the CRITFC, NMFS, USFWS, U of I, and others. This effort was supported by funding from the BPA.

\title{
PROGRAM GOALS AND OBJECTIVES
}

\begin{abstract}
Program Goal
Provide fisheries managers with information and recommendations for use in improving the survival of wild and hatchery yearling chinook salmon migrating to Lower Granite Dam from production areas in the Snake River Basin. Emphasis will be on obtaining information useful for managing wild populations.
\end{abstract}

\section{Research Goal}

Determine timing, location, magnitude, and cause of mortality for wild and hatchery yearling chinook salmon smolts above Lower Granite Dam.

\section{Program Objectives}

1. Determine survival rates and migrational characteristics from tributary production areas and release sites to Lower Granite Dam for wild and hatchery yearling chinook salmon smolts. 
2. Identify factors affecting mortality and migrational characteristics of wild and hatchery yearling chinook salmon smolts above Lower Granite Dam.

Obtaining reliable estimates of survival and travel time for wild and hatchery stocks of yearling chinook salmon is a necessary first step in the LGMS. For the most part, research on factors affecting smolt mortality and migrational characteristics (Objective 2) will begin after determining when and where mortality occurs. However, developing and testing the techniques necessary for reliable survival estimation will take several years. There is already sufficient evidence that excessive mortality exists to begin investigating causes. These investigations can often be easily integrated with ongoing survival/travel time or other studies. Potential factors affecting mortality and migrational characteristics include:

1. Environmental factors

2. Smolt condition and disease

3. Predation

4. Food availability

5. Wild and hatchery smolt interactions

While it is recognized that some or all of these factors are interdependent, each is discussed separately below. The following section suggests experimental approaches to address the program objectives, but should not be considered all-inclusive nor prescriptive. Details and logistics for any particular study will be addressed in research proposals submitted by individual investigators. 


\section{EXPERIMENTAL APPROACHES}

Objective 1. Determine survival rates and migrational characteristics from tributary production areas and release sites to Lower Granite Dam for wild and hatchery yearling chinook salmon smolts.

\section{Background}

Raymond (1979) began studies in 1964 to estimate survival of wild chinook salmon smolts outmigrating from the upper Salmon River to Ice Harbor Dam, then the uppermost dam on the lower Snake River. Smolts were freeze branded at traps located on the Salmon River, and subsequently recovered from gatewells or the sluiceway at the dam. Capture-efficiency curves were used to expand recovered fish numbers and estimate total passage of fish at the dam. Beginning in 1968, hatchery fish were also marked. When Little Goose and Lower Granite Dams were built, quantitative estimates of fish arriving at those sites were also made.

Giorgi (1991) calculated a survival index based on recoveries of marked fish at LGR. Fish marked with either PIT tags or freeze brands were counted, and the count was expanded by a generalized, constant FGE estimate (53\%). Indices were calculated only during years of no spill at LGR to avoid data distortion due to uncertain variables such as spill efficiency. These indices were only approximate estimates of survival, as they lacked definable statistical properties.

Kiefer and Forester (1990) estimated survival from release sites in tributaries of the Salmon River to the head of LGR Reservoir. Marked tributary releases of PIT-tagged fish were 
considered treatment groups. PIT-tag releases from IDFG traps in the Snake and Clearwater Rivers near Lewiston were considered controls. The ratio of recoveries at LGR to total fish released provided the survival estimate for the reach from the dam to the trap site.

Buettner and Nelson $(1990,1991)$ calculated a "minimum survival estimate" from cumulative PIT-tag recovery percentages at LGR, Little Goose, and MCNary Dams. However, this estimate was not adjusted for FGE, spill, or other factors that could affect its accuracy.

Both historic (Raymond 1979; FPC 1988) and current estimates of survival (Buettner and Nelson 1991; Kiefer and Forster 1990; Giorgi 1991) have been based on assumptions that may not be correct for recoveries of all marked fish. For example, collection efficiency at dams can change due to varying levels of smolt development (Giorgi et al. 1988; Muir et al. 1988, 1990) and subsequent behavioral changes (Muir et al. 1988). Smolt readiness in fish complicates survival estimations by affecting travel time and FGE. Nonetheless, because a significant loss of smolts apparently occurs before arrival at LGR, it is important to isolate mortalities occuring after release and but before recovery at LGR. Studies proposed for the LGMS to estimate survival should, at a minimum, produce good estimates of travel time through various reaches. Although not a measure of survival, travel time estimates may indicate areas of substantial delay, which are a likely indirect cause of mortality. LGMS 
studies will also attempt to determine smolt distribution patterns and movement within LGR Reservoir, especially in the forebay. This information may provide indications of areas where smolt mortalities occur.

\section{Potential Methods of Evaluation}

Determining where fish mortality occurs upstream from LGR will help focus other research efforts. Depending upon the accuracy and precision desired for loss estimates, methods employed to evaluate potential problem areas might vary. the following are three potential methods for survival estimation: 1) Use efficiency releases upstream from LGR to measure collection efficiency, then adjust mark recoveries from upstream areas by collection efficiency, 2) Assume constant collection efficiency of fish and then directly compare recovery rates of different groups of fish, and 3) Use re-release methods based upon methodologies proposed by Skalski and Giorgi (1992).

Development of new techniques and technologies should be encouraged as an alternative to, or in conjunction with, standard mark-recapture methods to estimate survival and travel time. The proposed acoustic PIT tag-offers potential capabilities that would be useful to the LGMS; however, development and evaluation of this tag will take many years. Another new technology which may be applicable is radio telemetry, which uses radio tags smaller than those currently available. Low cost, efficient mass-marking techniques for hatchery stocks would also be beneficial to the LGMS and other studies. Efforts to develop 
these techniques could be included in the LGMS or pursued independently.

Survival and travel-time studies could be divided into three general reaches: 1) from tributary production areas or hatchery release site to LGR, 2) from the head of the reservoir to LGR, and 3) within LGR Reservoir to the dam. The methods used would vary depending on the reach of interest.

Reach 1. From tributary production areas or hatchery release sites to Lower Granite Dam: Estimate travel time and survival of wild and hatchery stocks.

Efforts are currently underway to develop single-release survival estimation methods to yield statistically definable estimates of smolt survival from any upstream release site to the tailrace of a downstream dam (Skalski and Giorgi 1992). Estimates would include instream and dam effects. A pilot study to test this method could be initiated in 1993. Initial studies might include an assortment of chinook salmon hatchery stocks and possibly wild stocks.

The proposed method will require re-release of all PIT-tagged fish through the slide gate at LGR. It will also require an independent assessment of detector/re-release effects.

Reach 2. From river or reservoir trap sites to Lower Granite Dam, estimate travel time and survival of wild and hatchery yearling chinook salmon.

Experimental fish would be collected during the spring migration at trap sites on the Salmon and/or Snake Rivers and in 
LGR Reservoir. Travel time and survival estimates from capture sites to LGR could be made using the methods proposed for Reach 1. Smolts for PIT-tagging would be captured at existing smolt traps at Lewiston. New trap sites in the lower Salmon River and at the mouth of the Middle Fork of the Salmon River should also be considered. Additional study fish could also be collected from LGR Reservoir at one or more locations, using whatever capture method proved most effective. Possible capture methods include beach seining, purse seining, and two-boat trawling.

Better migrant traps with higher capture efficiencies for use in reservoir and river areas would substantially improve the ability to estimate survival and travel time. Wild fish will be distinguished from hatchery fish at the trap site by the absence of external marks, since all hatchery fish will be marked before release, beginning in 1993. Fish could also be PIT tagged at the trap site and released after a brief recovery period, and several daily releases could be pooled to increase sample size.

If wild migrant chinook salmon survive at the high rates Raymond (1979) estimated (85 to 95\%), then relatively small sample sizes could be used. Releases from these river and reservoir trap sites would provide travel time and survival estimates throughout different sections of the migration corridor for both wild and hatchery smolts. Differences in travel time and survival between release sites and release times would help isolate areas and times where high mortality occurs. 
Reach 3. From sequential reservoir release sites to Lower Granite Dam, estimate travel time and survival for wild and hatchery yearling chinook salmon.

Study fish would be sampled from the collection system at LGR, PIT-tagged, and transported to upstream release sites. Fish would be held in net pens for recovery prior to release. Three simultaneous releases of PIT-tagged smolts would be made: near Lewiston, at a mid-reservoir location, and in LGR forebay. This tagging and release process would continue periodically as long as sufficient numbers of fish were available. Estimates of travel time and survival could be made using methods similar to those used in Reaches 1 and 2 . Since fish would be released and recovered over a short time period, it may be possible to assume constant collection efficiency at the dam.

Alternatively, simultaneous releases of PIT-tagged hatchery smolts, held in the reservoir for various lengths of time, could be made at the same locations. Using hatchery smolts would eliminate the problems associated with recapturing and marking fish of mixed origin. Furthermore, this would allow continuous sampling for disease and smolt development profiles through hatchery residence and reservoir rearing.

Differences in travel time and survival between release points and release times, and information from disease/physiological profiles would help isolate locations and times of high mortality and identify possible causes.

As an alternative to, or in conjunction with, direct survival or travel time estimation, side-scan sonar could be used to 
discern possible areas of high smolt density or staging. Boats mounted with hydroacoustic equipment could periodically sample transects along the migration corridor to determine yearling chinook salmon distribution patterns. Traditional sampling methods for estimating relative abundance might also be used.

Objective 2. Identify factors affecting mortality and migrational characteristics of wild and hatchery yearling chinook salmon smolts above Lower Granite Dam.

\section{A. Environmental Factors}

Background

In the absence of adequate smolt survival estimates for yearling chinook salmon, travel time has been adopted as an index of performance. Decreased travel time is thought to increase survival. This premise is the foundation for various flow augmentation strategies currently being considered for the Columbia River Basin. There is evidence that a variety of environmental and biological factors influence migrational timing and speed, including river flow levels (Raymond 1979; Sims and Ossiander 1981; Buettner and Nelson 1990, 1991; Berggren and Filardo, in press; FPC 1991, 1992), water temperature (Raymond 1979), rainfall (Yamauchi et al. 1985), time of day, turbidity (Solomon 1978), and level of smolt development (Zaugg et al. 1985; Beeman et al. 1991; Muir et al. 1992). Of these factors, water velocity and the level of smolt development appear to be the most influential with regard to yearling chinook salmon migration speed or travel time (Beeman et al. 1991; Muir et al. 
1992; Berggren and Filardo, in press). Evaluations that strive to identify and quantify effects on migration speed must consider all of these important independent variables. To date, many investigations have been limited in scope: consequently, the results have been confounded and the effects of various environmental and biological factors have been indistinguishable. Potential Methods of Evaluation

Approach 1. Increase turbidity for migrating smolts in Lower Granite Dam forebay--Increased turbidity, often associated with rainfall or increased flow, reportedly increases salmonid migration rates (Solomon 1978; Sigler et al. 1984; Yamauchi et al. 1985). It is thought that turbidity causes smolts to lose station through reduced visual cues. This hypothesis is supported by diel passage behavior exhibited by smolts at mainstem dams. Increased turbidity may also increase FGE at dams (D. Bregei) and reduce predation rates by northern squawfish (Shively et al. 1991).

Turbidity in the Snake River has probably been reduced from historic levels because of reduced flows and dam construction. However, increases in turbidity still occur each spring, and have been associated with large increases in smolt passage at LGR (FPC 1992).

To test the hypothesis that increased turbidity will stimulate smolt migration, dredge material could be deposited

'Dean Brege, National Marine Fisheries Service, P.0. Box 97, Rufus, OR 97050-0097. Pers. Commun., August, 1992. 
into the water upstream from LGR forebay. The effects could be measured by releasing PIT-tagged smolts just prior to the test, and comparing their travel time to LGR with that of control fish released during a time of lower turbidity. Tests could be replicated several times to avoid confounding due to changes in flow conditions, temperature, or smolt development over the migration period. Actively migrating smolts could be captured at the head of the reservoir, PIT-tagged, and released after a short recovery period. A second measure of turbidity effects could be taken by comparing changes in daily turbidity with changes in daily smolt passage estimates at LGR. Changes in smolt distribution could also be monitored with hydroacustics.

Dredge material could be provided by the U.S. Army Corps of Engineers (COE) from the Lewiston area. This material has been examined for pollutants (dioxin, heavy metals, etc.), and found to be within acceptable standards according to the Environmental Protection Agency (COE 1991).

The effects of moderate increases in turbidity on salmonids have been found to be minimal in the short term (Servizi 1990; Sigler 1990). Since salmonids have evolved to migrate during times of increased turbidity, negative impacts should not be expected. However, to evaluate the effects of artificially induced turbidity, smolt condition should be monitored at LGR using the appropriate methods to ensure that increased turbidity does not cause undue stress or injury. 
Approach 2. Use multivariate analysis to define the relationship between smolt travel time and survival to Lower Granite Dam and important independent variables--Activities and protocols used by Beeman et al. (1991) and Buettner and Nelson (1991) are appropriate for executing such an analysis. Serial releases of PIT-tagged migrants from trap sites upstream from LGR, coupled with measures of important environmental and biological variables for each group, will provide useful data sets. An index of smolt development (i.e., gill $\mathrm{Na}^{+}-\mathrm{K}^{+}$ATPase) is required for each release group. Other biological variables such as size, condition factor, and incidence of disease should be considered (see following section on Smolt Condition and Disease). These analyses will require the acquisition of extensive data over several years. Since all hatchery fish will be marked beginning in 1993, it should be possible to collect separate data for wild and hatchery fish.

Approach 3. Conduct manipulative experiments so that effects due to flow are separable from those associated with the changing physiological status of the smolt population--Flow volumes typically increase over the course of the spring migration period. It has been observed during several years since 1987 that travel time of yearling chinook salmon to LGR decreases over this migration period (Buettner and Nelson 1991). Concurrently, the level of smolt development exhibited by the population increases. The combined influence of these independent variables confounds analysis and interpretation of travel time estimates. 
By disrupting the pattern of the typical hydrograph, it may be possible to create conditions where the effects of flow and smolt development can be evaluated separately. We recognize that the opportunity for intentional flow manipulation in the Snake River is constrained by limited water-storage capacity. However, this approach may be useful in certain flow years. Alternatively, retarding or accelerating the level of smolt development in migrants may be necessary to identify relationships between travel time and water velocity (Muir et al. 1992).

Approach 4. Profile water velocities in LGR forebay-Physical conditions in the LGR forebay may cause migrating smolts to congregate or stage for varying lengths of time. If this is true, water velocity profiles could be obtained using an acoustic doppler current profiler (ADCP). The USFWS is currently using this equipment in the Snake River for fall chinook salmon studies. An ADCP could be used in conjunction with hydroacoustic gear to determine where smolts reside in the forebay and under what hydraulic conditions. Smolts could be marked with PIT tags or miniature radio tags to monitor the effects of changing operating conditions at LGR, such as turbine loading, spill, and reservoir elevation. Smolt congregation or staging patterns may reflect changes in water velocities.

Approach 5. Measure water velocities at different flow levels in Lower Granite Reservoir--Water velocities along transects in LGR Reservoir could be measured at various flow 
levels using current meters or an ADCP. This information would be required to determine how varying levels of flow or reservoir elevation affect water velocity in the reservoir.

\section{B. Smolt Condition and Disease}

Background

Fish condition is defined as the physiological status of a fish and includes the stage of development (smoltification in migrants), and the ability of the fish to perform activities necessary for survival (such as swimming, predator avoidance, prey acquisition, and osmoregulation). Fish health is a component of fish condition and involves interactions between disease resistance, pathogens, and the environment.' Fish condition and fish health are intimately associated with other factors such as diet, environmental quality, and stress. Stress can be associated with entering a new environment, as when wild fish from a small tributary enter the mainstem or begin dam passage. Stress can also result from inter- and intra specific interactions between fish, such as predator avoidance, competition for limited resources, and new or increased exposure to a pathogen. It is important to monitor the various parameters of fish condition because fish with similar external appearances (i.e., no apparent lesions or physical damage) may have dissimilar internal functions, resulting in differential survival.

The relations between physiological changes during smoltification, disease, travel time, and survival are very 
complex. Cause and effect relationships have not been satisfactorily established, and there are varying opinions as to whether river flow or physiological condition is most important for reducing travel time (Beeman et al. 1991; Kindley 1991;

Berggren and Filardo, in press). It has been shown that gill $\mathrm{Na} \mathrm{K}^{\prime}$ ATPase (ATPase) level increases during smoltification (zaugg et al. 1985), and this enzyme is commonly used as a measure of smoltification. Some studies suggest that for hatchery fish, later release dates result in faster travel times (Chapman et al. 1991; Kindley 1991) because the fish have become more fully smolted and ready to migrate.

Muir et al. (1992) reported that increased water temperature and advanced photoperiod resulted in yearling chinook salmon smolts with higher levels of ATPase at release. Fish exposed to this treatment exhibited faster migration, and higher detection rates at dams, suggesting higher survival rates than controls. However, some data suggest that fish with higher ATPase levels have higher FGE at dams than those with lower levels (Giorgi et al. 1988; Muir et al. 1990). Furthermore, greater increases in ATPase occur during migration (Beeman et al. 1990; 1991) than during prolonged hatchery rearing.

Bacterial kidney disease (BKD) is widespread in Columbia River Basin hatchery and wild chinook salmon (Beeman et al. 1990; 1991; Elliot and Pascho 1991, 1992) and may be responsible for low survival of some stocks (Park et al. 1986; Matthews et al. 1987). Beeman et al. (1991) have shown that hatchery yearling 
chinook salmon collected at dams had a higher incidence and severity of BKD infection than occurred in the same groups prior to release. This apparent change may be the result of high-BKD fish being guided more efficiently by fish bypass systems than low-BKD fish (Elliot and Pascho 1991). However, other work has shown that salmonid immune responses are reduced (Maule et al. 1987), cortisol response to stress is increased (Barton et al. 1985) and sensitivity to cortisol is increased (McCormick et al. 1991; Maule et al. 1989) during smoltification. Thus, it is reasonable to expect that yearling chinook salmon are more susceptible to disease during their seaward migration. These studies illustrate the complexity of interactions between physiological development, environment, and estimates of smolt survival. These variables must be considered when attempting to identify factors affecting the survival and migrational characteristics of salmonids.

One goal of monitoring fish condition and health is to identify dysfunction affecting fish survival that may be linked to alterations in the river or hatchery environment. Another goal of monitoring is to develop reasonable predictions of fish performance and survival based on fish condition, fish health, and environmental conditions. Ideally, these predictions would project to adulthood; however, they can be projected more reasonably between two or more sampling points in the Columbia River Basin. 
Potential Methods of Evaluation

Approach 1. Assess the condition and health of migrating wild yearling chinook salmon in the Snake River Basin--Early in their migration, wild fish would be collected in tributaries and sampled non-lethally to determine fish physiological condition and health. A smaller subsample of wild yearling chinook salmon could be killed to develop a more complete physiological profile and to screen for the presence of fish pathogens.

Approach 2. Determine the degree of difference in fish condition and fish health between wild and hatchery yearling chinook salmon--If wild fish are in good condition at the time they begin migration, it is reasonable to assume that unusually high mortality is a function of environmental conditions. This assumption also implies that the more closely hatchery fish approach wild fish physiologically, the greater the likelihood of their successful migration to seawater and survival to maturity.

One approach is to collect yearling chinook salmon from the wild, raise them with hatchery fish in a common environment (e.g., net pens, artificial streams, hatchery raceways) and monitor fish condition and fish health. If it appears that significant mortality occurs in LGR Reservoir, net pens could be designed for movement of fish through the reservoir at rates similar to those of migrating fish. Frequent monitoring of fish condition and health would indicate whether mortality was caused by factors intrinsic to the fish or to the reservoir environment. 
Fish in these experiments should be held at very low densities, in conditions as close to natural as possible.

The USFWS is beginning a study of the genetic differences between hatchery and wild spring chinook salmon in the lower Columbia River at Carson and Warm Springs NFHs. The experimental design involves collecting wild and hatchery adults, crossing wild and hatchery fish, and rearing all sets of progeny (hatchery, wild, and wild-hatchery crosses) in hatchery and wild environments. In this study, fish condition, fish health, and other factors will be monitored. Baseline data on differences between wild and hatchery fish that are attributable to environment or life history will be directly applicable to the LGMS .

Approach 3. Develop non-intrusive methods to assess fish condition and health--Because wild yearling chinook salmon are a threatened species, the use of nonlethal techniques is desirable. A suite of nonintrusive measures of the degree of smoltification, including skin reflectance, condition factor, and morphometrics should be available soon. An assay for gill ATPase that requires clipping a small amount of gill tissue (micro sample), but not killing the fish, should be available by 1993. Screening for fish pathogens requires killing fish; however, there are potentially nonlethal methods of determining fish health by examining immune components in fish mucus.

An ideal regimen at a smolt trap or collection facility would be to sample tagged fish nonintrusively for smolt condition, 
micro sample gill tissue for ATPase assays, and sacrifice a small number of fish for pathogen screening.

Approach 4. Assess fish condition and fish health of PITtagged groups at time of release from hatcheries, during their migration, and at Lower Granite Dam--It is recommended that fish from several hatcheries be PIT tagged and released over a period of time (see Objective 1). All, or a large sample, of these fish could be examined nonintrusively to determine degree of smoltification. A small group of fish would have a microsample of gill removed nonlethally to determine gill ATPase. A second group of fish from the same pond or raceway would be killed for complete fish pathogen screening.

As PIT-tagged fish are collected in-river, during their migration, and at LGR they will again be subjected to nonintrusive fish condition assessment and released. This would allow determination of the degree to which individual fish change during migration, and the influence of fish condition on survival and migration rate. Fish health and condition data collected at the time of tagging and recapture would add information to the multivariate equation that describes a successful migrant, whether the measure of success is survival, travel time, or some other performance standard.

Approach 5. Assess the effects of modified hatchery rearing practices on fish condition and fish health--There are many hatchery evaluation programs already in place (e.g., BPA's Hatchery Evaluation Program, Lower Snake River Compensation Plan 
Hatchery Evaluation, and individual state evaluations). The objective of this approach is to coordinate information obtained on fish under various hatchery rearing practices with subsequent measures of smolt development, fish health, travel time, and survival at in-river, reservoir, and Lower Granite Dam collection sites.

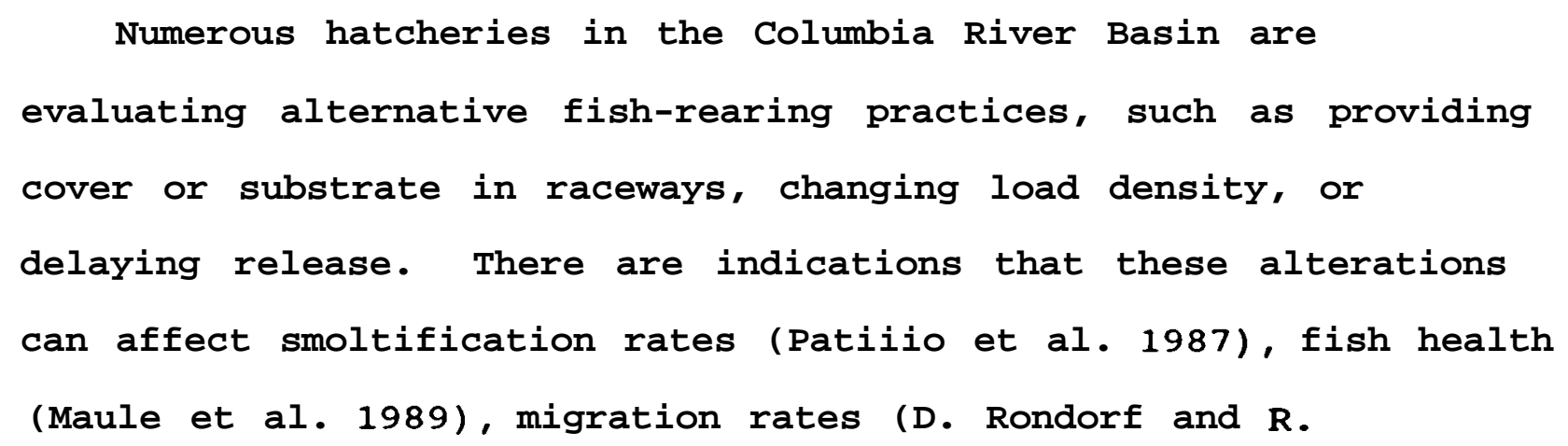

Hatchery fish subjected to alternative rearing conditions will be sampled prior to release. Fish from each treatment will be PIT-tagged or freeze branded (if they are not already) and sampled at collection points during their migration to LGR.

'Dennis W. Rondorf, U.S. Fish and Wildlife Service, National Fishery Research Center, Cook Field Station, MP 5.48L CookUnderwood Rd, Cook, WA 98605 and Ralph B. Roseberg, U.S. Fish and Wildlife Service, Fisheries Resource Office, Box 18, Ahsaka, ID 83520. Unpublished data. 


\section{Predation}

Background

Two ongoing studies have contributed most of the available information on predation on migrating yearling chinook salmon upstream from LGR. The first, sponsored by the COE and conducted by the U of $I$, began in 1979 to investigate warmwater fish habitat and dredging in the lower Snake River reservoirs (Bennett et al. 1983, 1988a,b, 1990, 1991; Bennett and Shrier 1986). The second study, sponsored by BPA and conducted jointly by ODFW and USFWS, indexed abundance of and consumption by predaceous fish in and slightly above LGR Reservoir. This work was conducted in 1991 as part of a system-wide study of predation (Shively et al. 1991; Ward et al. 1993).

Northern squawfish, Ptvchocheilus oreqonensis, and smallmouth bass, Micropterus dolomieui, are relatively abundant in LGR Reservoir and are known to consume juvenile salmonids. Sampling with a variety of gears through several seasons and diverse habitats, $U$ of $I$ researchers determined that northern squawfish and smallmouth bass were among the top four (of 10) most abundant species in the reservoir in 1979 and 1980 (Bennett et al. 1983). Northern squawfish were less abundant and smallmouth bass were more abundant in LGR Reservoir than in other reservoirs on the lower Snake River (Bennett et al. 1983).

Sport-reward fishers participating in the BPA-funded predator control program caught 20,994 northern squawfish greater than 250 mm long in LGR Reservoir in 1991 (Burley et al. 1993). This is 
more than three times the number removed from any other lower Snake River reservoir. However, catch per unit of effort (CPUE) was similar among the four reservoirs, suggesting that densities of northern squawfish in LGR Reservoir are similar to those in the other reservoirs.

Salmonids compose substantial portions of the diets of northern squawfish and smallmouth bass during the smolt migration, and represented 19 to nearly 50\% (wet weight) of the gut content of fish sampled during that period (Bennett and Shrier 1986; Bennett et al. 1988a,b; Shively et al. 1991). Smolt consumption indices for northern squawfish in LGR Reservoir in 1991 were comparable to those for analogous areas of Little Goose Reservoir, but greater than those of the other two lower Snake River reservoirs, and less than those for John Day Reservoir (Shively et al. 1991).

Smallmouth bass, particularly large ones, also consume many smolts in LGR Reservoir. In the spring of 1985, salmonids composed $26 \%$ and $13 \%$ of the gut contents (wet weight) of smallmouth bass sampled at shallow and deep stations, respectively, in LGR Reservoir. These percentages exceeded those for northern squawfish sampled at the same times and locations (Bennett and Shrier 1986). Conversely, in 1987, salmonids accounted for only $1 \%$ of an index of relative importance for the diet of smallmouth bass ( $\geq 150 \mathrm{~mm}$ ). This percentage is much lower than the analogous value obtained for northern squawfish (Bennett et al. 1988b). In 1991 predator consumption indexing, 
samples taken in and above LGR Reservoir had higher average numbers of salmonids per smallmouth bass of a given size class than did samples from other reservoirs in the lower snake River, although average numbers were generally low $(<0.5$ smolts per fish, overall) (Shively et al. 1991). Of the smallmouth bass that had consumed smolts, $90 \%$ were $\geq 280 \mathrm{~mm}$ (Shively et al. 1991). Low water temperatures during the smolt migration may suppress predation by smallmouth bass (Bennett et al. 1983). Other species of predaceous fish inhabit LGR Reservoir, but appear to have less impact on smolt populations than do northern squawfish and smallmouth bass. Channel catfish, Ictalurus punctatus, are less abundant in LGR Reservoir than in other lower Snake River reservoirs (Bennett et al. 1983) and are less abundant in LGR Reservoir than northern squawfish and smallmouth bass (Bennett et al. 1983, 1988a,b, 1990, 1991; Bennett and Shrier 1986; Shively et al. 1991). The few gut samples obtained from channel catfish in LGR Reservoir show highly variable smolt consumption rates relative to those of northern squawfish and smallmouth bass in the same years. Channel catfish also consume a higher proportion of steelhead (Bennett and Shrier 1986; Bennett et al. 1988a,b). The impact of smolt predation by channel catfish appears to be much greater below LGR, even at fairly low water temperatures $\left(10^{\circ} \mathrm{C}\right)$, where as many as $41 \%$ of catfish sampled contained smolts (Bennett et al. 1983).

Although much attention is now focused on control of northern squawfish, predation is more than a single-species issue. Larger 
yellow perch, Perca flavescens, and white crappie, Pomoxis

annularis, may also consume salmonids in LGR Reservoir (Bennett and Shrier 1986). Brook trout, Salvelinus fontinalis, and common mergansers have been observed preying on chinook salmon fry in small streams in the Snake River Basin above LGR Reservoir (Welsh 1988). Although flocks of common mergansers are widely distributed throughout the Clearwater and Salmon River Basins, their effect on chinook salmon may be very localized (C. Petrosky'). Other potential avian predators include herons, gulls, and belted kingfishers. Large hatchery steelhead are also potential predators on chinook salmon, especially on smaller smolts.

There is a paucity of information about predation on yearling chinook salmon in mainstem reaches above LGR Reservoir. Reaches of the Clearwater River (RKm O-6) and the Snake River (RKm 229238 and 268-276) were sampled for predator consumption indexing in 1991, although only the latter reach on the Snake River (RKm 268-276, "Rogersburg", near the mouth of the Grande Ronde River), was identified as free-flowing (Shively et al. 1991). "High numbers" of salmonids were consumed by northern squawfish in these three areas and in the upper part of LGR Reservoir following local hatchery releases. Catch rates of northern squawfish were also relatively high in these areas and times.

\footnotetext{
'Charles Petrosky, Idaho Department of Fish and Game, 600 S. Walnut, Boise, ID 83707. Pers. Commun., August, 1992.
} 
There are numerous anecdotal observations of northern squawfish (many of them very large fish) that concentrate in streams above LGR in the spring and early summer. It is unknown whether these are spawning or feeding concentrations, although they readily attack lures and sometimes concentrate downstream from hatchery release points.

Some researchers advise that studies should extend upstream to hatchery release points or natural production areas.

Predators in the reservoir and in the lower reaches of major tributaries (e.g., Clearwater, Grande Ronde, Imnaha, and Salmon Rivers) may have overlapping ranges and may belong to the same "populations" during some seasons. Hence, studies should not exclude either the impounded or free-flowing areas. Although predation on chinook salmon stocks occurs through the egg, alevin, fry, and parr life stages, these life stages are outside the present scope of the LGMS.

Because of potential compensation among predators and prey, an ideal study would address the structure and function of the fish communities. For example, does the presence of abundant hatchery smolts ameliorate or exacerbate predation rates on natural smolts?

In conclusion, it is clear that smolts fall prey to predaceous fish in LGR Reservoir, particularly northern squawfish and smallmouth bass. However, it is uncertain whether predation is a major source of mortality for wild and hatchery yearling chinook salmon above LGR. 
Potential Methods of Evaluation

Approach 1. Estimate predation rates on specific stocks of wild and hatchery yearling chinook salmon--We need sound estimates of the proportion of hatchery and wild yearling chinook salmon smolts that are preyed upon by various predators in a given time period and locale. The role of predation in removing smolts that would otherwise die anyway, and factors that affect smolt vulnerability to predators but alone may not be lethal (e.g., disease, starvation), must also be considered.

Proposed methods must not only offer the desired level of precision, but must be able to adjust to changing levels of prey and predator abundance. Northern squawfish control efforts in and above LGR Reservoir, which began in 1991, are likely to continue and will probably change the northern squawfish population and the fish community as a whole. The sport-reward fishery reportedly removed nearly 21,000 northern squawfish ( $\geq$ $250 \mathrm{~mm}$ ) from the reservoir in 1991 alone (Burley et al. 1993).

Flow and reservoir-level management will change the reservoir environment from year to year, and there is some evidence that the fish community has already been changed markedly by the drawdown of LGR Reservoir in March 1992 (D. Bennett'). Smolt abundance may also change with management changes, which could influence indices and predation rates. LGR Reservoir and the free-flowing reaches upstream may require different experimental

'David Bennett, University of Idaho, Department of Fish and wildlife, Moscow, ID 83843. Pers. Commun., August, 1992. 
approaches because of fundamental differences between impounded and free-flowing environments.

Because of the potential for intra-specific and communitylevel compensation from predator removal, functional and demographic changes in the fish community should be monitored.

Approach 2. Indexing-- Previous and ongoing predation studies have indexed predator abundance and consumption (Bennett et al. 1983; Ward et al. 1993). Some researchers recommend that these indexing methods, supported with a more intensive sampling effort, would provide sufficient information.

The ODFW and USFWS have developed a predation index that numerically combines indices of predator abundance and consumption of salmonids (Viqq and Burley 1990). The predator abundance index is the mathematical product of the following factors: 1) the natural logarithm of non-zero catches for standardized efforts of boat electroshocking within a reservoir and, 2) the reservoir surface area, excluding mid-channel and deep areas (Ward et al. 1993).

The consumption index (for northern squawfish), calculated for portions of each reservoir, is a function of water temperature, mean predator weight, mean number of salmonids per predator, and mean gut weight per predator (Shively et al. 1991). The consumption index is not meant to be a rigorous method for estimating the number of salmonids eaten per day by an average predator (Petersen et al. 1990). A predation index, the mathematical product of the abundance and consumption indices for 
a reservoir, is believed to be directly proportional to differences in predation among reservoirs or parts of reservoirs. However, this index is not an estimate of the number of salmonids consumed by northern squawfish (Ward et al. 1993). Indices are relative, require careful standardization in sampling to avoid biases, and do not lend themselves to firm estimates of precision.

Approach 3. Computer simulation modeling--Computer simulation models have been used to estimate salmonid mortality from predation. The Columbia River Ecosystem Model (CREM) has been developed under the BPA-sponsored Predator Control Program to predict smolt mortality during downstream migration (Bledsoe 1990). In general, CREM estimates predation rate as a function of predator-fish density, water temperature, spawning condition of predators, and density of salmonid prey (Bledsoe et al. 1990). Bioenergetics modeling has been recommended as another potentially useful tool, if reasonable estimates of predator populations can be obtained (Petersen et al. 1990; Shively et al. 1991).

\section{Food Availability}

Background

Bennett and Shrier (1986) and Bennett (D. Bennett ${ }^{5}$ ) sampled stomachs of migrating chinook salmon smolts in LGR Reservoir. Although both studies reported a wide range in the types of food

David Bennett, Unpubl. data, University of Idaho, Department of Fish and Wildlife, Moscow, ID 83843. 
consumed, chironomid larvae predominated. Most fish sampled contained food items and numerous stomachs were full. However, some individuals lacked food and others contained exuviae that are nutrient poor (D. Bennett'). In contrast, yearling chinook salmon smolts sampled from turbine intakes at LGR in 1987, 1989, and 1991 had a high percentage of empty stomachs compared to smolts collected at other dams (W. Muir and T. Coley ${ }^{c}$ ). These contrasting results may reflect differences in prey availability and/or feeding success within LGR Reservoir.

The abundance of potential food items in the Snake River Basin has not been intensively studied. Dorband (1980) sampled LGR Reservoir with artificial substrates and core samples and reported high benthic diversity. Bennett and Shrier (1986) and Bennett et al. (1988b, 1990, 1991) quantified benthos density and standing crop in LGR Reservoir. These studies found numerous changes in the benthic community after impoundment, including a substantial decrease in diversity and abundance. The present LGR Reservoir benthic community is relatively "simple" with a composition of nearly 97\% oligochaetes and chironomids (Bennett et al. 1988b, 1990, 1991).

In 1990, approximately 21 million salmon and steelhead were released from hatcheries above LGR to mitigate for losses from hydroelectric development (FPC 1991). Yearling chinook salmon of hatchery origin are usually released as inadequately developed

'William D. Muir, Unpubl. data, National Marine Fisheries Service, Star Rt, Cook, WA 98605 and Travis C. Coley, U.S. Fish and Wildlife Service, 9317 HWY.99, Suite A, Vancouver, WA 98665. 
smolts (Zaugg et al. 1991), a condition resulting in slow migration. For example, yearling chinook salmon from Dworshak NFH spend from 3 to 4 weeks in LGR Reservoir (Giorqi et al. 1990, 1991; Muir et al. 1992), a length of time previously sufficient for their entire downstream migration. Salmonids actively feed during their migration through the Columbia River to offset energy depletion (Rondorf et al. 1985; Muir and Emmett 1988). The increasing number of smolts and their protracted residence time has raised concern about the capacity of the forage base in LGR reservoir to support them.

Potential Methods of Evaluation

Approach 1. Evaluate the food habits and nutritional status of downstream migrating smolts--The food habits and nutritional status of yearling chinook salmon smolts could be sampled at selected locations and times during the migration. Lavage could be used for sampling stomachs, which would not require sacrificing smolts. Diet composition, stomach fullness, and other indices of feeding success could be related to characteristics of physical well being, such as growth rate, condition factor, level of smolt development, and disease state. Feeding success could also be a function of origin (hatchery or wild) .

Approach 2. Conduct in situ rearing experiments in Lower Granite Reservoir--Fed and unfed smolts could be confined in net pens in LGR Reservoir, PIT-tagged and periodically released. Treatment effects could be measured in terms of smolt and disease 
development, swimming performance, migrational characteristics, and detection proportions downstream.

Approach 3. Determine the abundance and availability of food items for yearling chinook salmon throughout the downstream migration corridor to Lower Granite Dam--Information is lacking on the availability of benthic food items (particularly chironomids) to migrating smolts in the Snake River Basin. Although community biomass and productivity in LGR Reservoir is comparable to other systems (C. Falter'), oliqochaetes are generally unavailable, and chironomids are available only during emergence. The high incidence of empty smolt stomachs observed at LGR suggests that food availability or feeding sites may be limited in certain areas, and may adversely affect survival in LGR Reservoir.

Approach 4. Model the bioenergetics of downstream migrating smolts--A bioenergetics approach similar to that conducted by Rondorf et al. (1985) could be used to assess smolt energy requirements during downstream migration. A bioenergetics model that incorporates data from laboratory and field studies could be developed to evaluate the ability of the system to support varying numbers of hatchery and wild migrants. This information would have application to other Snake River reservoirs.

'C.M. Falter, University of Idaho, Department of Fish and Wildlife, Moscow, ID 83843. Pers. Commun., August, 1992. 


\section{E. Wild and Hatchery Interactions}

Background

Hatchery and wild chinook salmon have similar ecological requirements and thus are potential competitors if they co-occur where critical resources are in short supply. Although little is known about competition among actively migrating smolts, an inability to compete effectively for food and space has often been cited as a reason why many juvenile salmonids reared in hatcheries do not survive in the wild (Steward and Bjornn 1990). Competition and its effects on survival are typically difficult to demonstrate, particularly under field conditions. For this reason, the following approaches are suggested: 1) identify the means by which chinook salmon smolts compete for and defend needed resources, 2) determine whether resource demand exceeds availability, and 3) evaluate the effects of resource deprivation (or increased energy demands) on survival and other measures of smolt performance. From these lines of evidence, the occurrence of competition may be inferred and its relative importance assessed.

Some of the ways that hatchery smolts might affect the survival of wild smolts include attracting and supporting larger predator populations, altering migratory behavior or activity levels, and transmitting disease. The outcome of these kinds of interactions depends on the relative abundance of hatchery and wild fish and the degree that they overlap in time and space. Other types of interactions between hatchery and wild 
populations, such as genetic changes that might result from hybridization, may affect the long-term fitness of smolts. One consequence of such a change might be a reduction in smolt survival during outmigration.

Interspecific interactions could also be occurring between the increasing numbers of hatchery steelhead, which are much larger than wild steelhead, and chinook salmon smolts. Steelhead have been reported to prey on small chinook salmon smolts, elevate chinook salmon stress levels (Park et al. 1984), and possibly compete for food. These interactions could be particularly acute at LGR.

Wild/hatchery interactions are not a direct mortality factor, but increase the likelihood of mortality from one of the factors previously discussed. If hatchery and wild chinook salmon smolts survive at different rates, or if survival rates are unacceptably low for either or both, it is reasonable to ask whether the presence of one somehow affects the survival of the other. If competition within or between groups of hatchery and wild smolts is density-dependent, or if predation intensity, food availability, or disease transmission is related to smolt density, some form of negative effect on growth and survival will likely occur as smolt density increases.

Potential Methods of Evaluation

Approach 1. Determine whether the survival of hatchery and wild smolts is related to their absolute and relative abundance-General techniques to measure smolt abundance were outlined above 
in the section addressing Objective 1 . This will probably require obtaining estimates of hatchery and wild chinook salmon and steelhead abundance at different times and locations during the migration period.

Alternatively, manipulating absolute and relative smolt abundance or density by releasing or postponing the release of hatchery fish onto groups of wild smolts might provide insight into the survival of fish. Introducing different ratios and densities of hatchery and wild fish into net pens that are towed a fixed distance downstream at normal migration speeds would provide a variation to this approach. Food availability within the net pens could be monitored and supplemented if desired. Predators, normally excluded from the net pens, might be introduced at different densities to enable comparisons of predation mortality among hatchery and wild smolts. The use of net pens, as described in earlier sections, enables replication and control over important biological factors.

Approach 2. Determine whether hatchery and wild chinook salmon smolts use different migratory routes and habitats-Differences in habitat use between hatchery and wild smolts might indicate noninteraction or displacement among the two groups and offer insight into the causes of apparently different levels of survival. To determine habitat use, mean densities of hatchery and wild smolts could be estimated within the boundaries of discrete habitats upstream from LGR Dam. Here, habitat is defined as generally homogeneous areas of river used by smolts 
for migration, feeding, resting, etc. The amount of time spent in each habitat and the type of activity pursued might be related to differences in survival over time.

Approach 3. Identify interactive behaviors that influence the survival of hatchery and wild smolts--Interactive behavior between hatchery and wild fish may affect their survival. For example, the dispersal characteristics of hatchery fish following release may have some bearing on their subsequent survival and on that of wild fish with which they interact. Studies to determine whether hatchery smolts immediately migrate or disperse for significant periods of time into nearby habitats occupied by wild fish before starting their downstream migration might show differences in survival. Dispersion patterns could be studied by direct underwater observation of marked hatchery smolts released into selected streams.

Understanding the behaviors of "typical" wild smolts and hatchery smolts exposed to similar stimuli might lead toward understanding of survival differences and interactive behaviors. Comparison of behavioral characteristics should make it possible to identify divergent behaviors that may directly (e.g., via schooling) or indirectly (e.g., via competition) alter a fish's chances of survival. Much of the work can be done in seminatural environments, such as artificial streams and net pens, to facilitate observation. 


\section{INTEGRATION WITH ONGOING RESEARCH AND MANAGEMENT ACTIVITIES}

Before initiating travel time/survival studies, current marking and recapture programs in the Snake River Basin will be evaluated. Expanding some current Smolt Monitoring Program activities could adequately address some LGMS objectives. PITtagged hatchery release groups from other work (SMP, hatchery evaluations, Idaho traps, etc.) could be used when possible to reduce marking requirements.

Supplementation studies will release PIT-tagged smolts in tributaries upstream from LGR Dam; however, it is uncertain whether these will meet the needs of this study. Often, these fish are tagged as parr, released well in advance of initiating downstream migration, and incur some overwinter mortality. Given that most supplementation groups contain only 500 PIT-tagged smolts (Bowles and Leitzinger 1991), detection numbers at IGR will probably be low. IDFG, ODFW, and NMFS will again PIT tag wild chinook salmon parr in tributaries. If tagging efforts and recovery proportions at LGR are similar to previous years, detection numbers will probably remain low.

For fish condition work, most of the sampled fish will be collected as part of the LGMS or other projects investigating survival and migration of wild and hatchery fish. Therefore, coordination of agencies and tribes will be essential to ensure that comparable methods are used and duplication of sampling is avoided. Coordination with hatcheries conducting rearing experiments may also be necessary. 


\section{RECOMMENDATIONS}

\section{Research Priorities}

1. Estimate survival and travel time for wild yearling chinook salmon smolts along the migration corridor using PIT tags. Existing marking programs may provide some information, but present smolt traps capture too few wild yearling migrants to mark for evaluation. New traps and weirs at upstream locations will be required. Purse seining (or some other method) may be required in LGR Reservoir to increase sample sizes for PIT tagging.

2. Conduct survival studies from selected hatcheries and downstream sites to quantify losses of hatchery smolts along the migration corridor. These studies should be closely coordinated with other marking programs.

3. Make simultaneous releases of PIT-tagged chinook salmon smolts in the forebay, mid-reservoir, and head of the LGR Reservoir to partition areas of migrational delay. Examine reservoir distribution patterns to identify possible staging areas.

4. Begin investigating factors that influence mortality and migrational characteristics when and where good evidence exists that those factors increase mortality or affect travel time.

5. Develop better migrant traps with higher capture efficiencies for use in reservoir and river areas. 
REFERENCES

Achord, S., J. R. Harmon, D. M. Marsh, B. P. Sandford, K. W. McIntyre, K. L. Thomas, N. N. Paasch, and G. M. Matthews.

1992. Evaluation of transportation of juvenile salmonids and related research on the Columbia and Snake Rivers, 1991. NMFS Research Report to U.S. Army Corps of Engineers, Contract DAW68-84-H0034, 57 p. (Available from Northwest Fisheries Science Center, 2725 Montlake Blvd. E., Seattle, WA 98112-2097.)

Banks, J. I .

1990. A review of rearing density experiments: Can hatchery effectiveness be improved? In D. L. Park (convener), Status and future of spring chinook salmon in the Columbia River Basin--Conservation and enhancement: Spring Chinook Salmon Workshop, 8-9 November 1989. U.S. Dep. Commer., NOAA Tech. Memo. NMFS F/NWC-187, p 94-103.

Barton, B. A., C. B. Schreck, R. D. Ewing, A. R. Hemmingsen, and R. Patiño.

1985. Changes in plasma cortisol during stress and smoltification in coho salmon, oncorhvnchus kisutch. Gen. Comp. Endocrinol. 59:468-471.

Beaty, R. E., B. L. Parker, K. Collins, and K. McRae. 1993. The use of controlled angling to manage northern squawfish populations at selected dams on the Snake and Columbia Rivers. In C. F. Willis and A. A. Nigro (editors), Development of a system-wide predator control program: Stepwise implementation of a predation index, predator control fisheries, and evaluation plan in the Columbia River Basin. Annual report 1991 to Bonneville Power Administration, Contract DE-BI79-90BP07084, p 111186. (Available from Bonneville Power Administration, Div. of Fish and Wildlife-PJ, P.O. Box 3621, Portland, OR 97208.)

Beeman, J. W., D. W. Rondorf, J. C. Faler, M. E. Free, and P. V.Haner.

1990. Assessment of smolt condition for travel time analysis. Annual Report 1989 to Bonneville Power Administration, Contract DE-AI79-87-BP35245, 103 p. (Available from Bonneville Power Administration, Div. of Fish and WildlifePJ, P.O. Box 3621, Portland, OR 97208.) 
Beeman, J. W., D. W. Rondorf, J. C. Faler, P. V. Haner, S. T. Sauter, D. A. Venditti.

1991. Assessment of smolt condition for travel time analysis. Annual Report 1990 to Bonneville Power Administration, Contract DE-AI79-87-BP35245, 71 p. (Available from Bonneville Power Administration, Div. of Fish and Wildlife-PJ, P.O. Box 3621, Portland, OR 97208.)

Bennett, D. H., P. M. Bratovich, W. Knox, D. Palmer, and H. Hansel.

1983. Status of the warmwater fishery and the potential of improving warmwater fish habitat in the lower snake reservoirs. Final Report to U.S. Army Corps of Engineers, Contract DACW68-79-C0057, 451 p. (Available from U.S. Army Corps of Engineers, Walla Walla District, Building 602, City-County Airport, Walla Walla, WA 99362.)

Bennett, D. H., and F. C. Shrier.

1986. Effects of sediment dredging and in-water disposal on fishes in Lower Granite Reservoir, Idaho-Washington.

Completion Report to U.S. Army Corps of Engineers, Contract DACW68-85-C-0044, 143 p. (Available from U.S. Army Corps of Engineers, Walla Walla District, Building 602, CityCounty Airport, Walla Walla, WA 99362.)

Bennett, D. H., J. A. Chandler, and I. K. Dunsmoor.

1988a. Fish and benthic community abundance at proposed in-water disposal sites in Lower Granite Reservoir, Washington. Addendum: Fish and habitat evaluation of shallow water habitats in Lower Granite Reservoir. Completion Report to U.S. Army Corps of Engineers, 140 p. (Available from U.S. Army Corps of Engineers, Walla Walla District, Building 602, City-County Airport, Walla Walla, WA 99362.)

Bennett, D. H., L. K. Dunsmoor, and J. A. Chandler.

1988b. Fish and benthic community abundance at proposed in-water disposal sites in Lower Granite Reservoir, Washington. Completion Report to U.S. Army Corps of Engineers, 253 p. (Available from U.S. Army Corps of Engineers, Walla Walla District, Building 602, City-County Airport, Walla Walla, WA 99362.)

Bennett, D. H., J. A. Chandler, and I. K. Dunsmoor.

1990. Lower Granite Reservoir in-water disposal test: Results of the fishery, benthic and habitat monitoring program-year 1. Completion Report to U.S. Army Corps of Engineers, 251 p. (Available from U.S. Army Corps of Engineers, Walla Walla District, Building 602, City-County Airport, Walla Walla, WA 99362.) 
Bennett, D. H., J. A. Chandler, and G. Chandler.

1991. Lower Granite Reservoir in-water disposal test:

Monitoring fish and benthic community activity at disposal and reference sites in Lower Granite Reservoir, WA, year-2 (1989). Completion Report to U.S. Army Corps of Engineers, 164 p. (Available from U.S. Army Corps of Engineers, Walla Walla District, Building 602, City-County Airport, Walla Walla, WA 99362.)

Berggren, T. J., and M. J. Filardo.

In press. An analysis of variables influencing the migration of juvenile salmonids in the Columbia River Basin. N. Am. J. Fish. Manage.

Bledsoe, L. J.

1990. Columbia River Ecosystem Model (CREM)--Modeling approach for evaluation of control of northern squawfish populations using fisheries exploitation. Report D In A. A. Nigro (editor), Developing a predation index and evaluating ways to reduce salmonid losses to predation in the Columbia River Basin. Final Report, August 1988 September 1990, to Bonneville Power Administration, Project 82-012, Contract DE-AI79-88BP92122, p. 206-338. (Available from Bonneville Power Administration, Div. of Fish and Wildlife-PJ, P.O. Box 3621, Portland, OR 97208.)

Bledsoe, L. J., S. Vigg, and J. H. Petersen.

1990. Simulation estimates of salmonid predation loss to northern squawfish in a Columbia River reservoir. Appendix D-1 In L. J. Bledsoe. Columbia River Ecosystem Model (CREM) --Modeling approach for evaluation of control of northern squawfish populations using fisheries

exploitation. Report D In A. A. Nigro (editor), Developing a predation index and evaluating ways to reduce salmonid losses to predation in the Columbia River Basin. Final Report, August 1988-September 1990, to Bonneville Power Administration, Project 82-012, Contract DE-AI79-88BP92122, p. 221-338. (Available from Bonneville Power Administration, Div. of Fish and Wildlife-PJ, P.O. Box 3621, Portland, OR 97208.)

Bowles, E., and E. Leitzinger.

1991. Salmon supplementation studies in Idaho rivers (Idaho supplementation studies). Experimental design. Bonneville Power Administration, Contract DE-BI79-89BP01466, 167 p.

(Available from Bonneville Power Administration, Div. of Fish and Wildlife-PJ, P.O. Box 3621, Portland, OR 97208. ) 
Buettner, E. W., and V. L. Nelson.

1990. Smolt monitoring at the head of Lower Granite

Reservoir and Lower Granite Dam. Annual Report of 1989 operations to Bonneville Power Administration, Contract DEBI79-83-BP11631, 59 p. (Available from Bonneville Power Administration, Div. of Fish and Wildlife-PJ, P.O. Box 3621, Portland, OR 97208.)

Buettner, E. W., and V. L. Nelson.

1991. Smolt monitoring at the head of Lower Granite

Reservoir and Lower Granite Dam. Annual Report of 1990

operations to Bonneville Power Administration, Contract DEBI79-83-BP11631, 72 p. (Available from Bonneville Power Administration, Div. of Fish and Wildlife-PJ, P.O. Box 3621, Portland, OR 97208.)

Burley, C. C., D. C. Klaybor, G. W. Short, and G. J. Hueckel. 1993. Evaluation of the northern squawfish sport-reward fishery in the Columbia and Snake Rivers. In c. F. Willis and A. A. Nigro (editors), Development of a system-wide predator control program: Stepwise implementation of a predation index, predator control fisheries, and evaluation plan in the Columbia River Basin. Annual report 1991 to Bonneville Power Administration, Contract DE-BI7990BP07084, p 41-110. (Available from Bonneville Power Administration, Div. of Fish and Wildlife-PJ, P.O. Box 3621, Portland, OR 97208.)

Ceballos, J.R., S. W. Pettit, and J. L. McKern.

1991. Fish transportation oversight team annual report-FY 1990. Transport operations on the Snake and Columbia Rivers. U.S. Dep. Commer., NOAA Tech. Memo., NMFS F/NWR$29,76 \mathrm{p}$.

Ceballos, J. R., S. W. Pettit, and J. L. Mckern.

1992. Fish transportation oversight team annual report FY1991. Transport operations on the Snake and Columbia Rivers. U.S. Dep. Commer., NOAA Tech. Memo., NMFS F/NWR$31,77 \mathrm{p}$.

Chapman, D., A. Giorgi, M. Hill, A. Maule, S. Mccutcheon, D. Park, W. Platts, K. Pratt, J. Seeb, L. Seeb, and F. Utter. 1991. Status of Snake River chinook salmon. Don Chapman Consultants, Inc., Report to Pacific Northwest Utilities Conference Committee, 251 p. (Available from Don Chapman Consultants, Inc., 3180 Airport Way, Boise ID 83705.) 
Corps of Engineers, U.S. Army (COE).

1991. Non-Federal navigation dredging and beneficial use of dredge material in the Columbia and Snake Rivers:

Environmental assessment with addendum. Appendix A:

Section 404 (b) (1) Evaluation. Appendix B: Navigation dredging sediment contamination investigation summary report. Appendix C: Biological assessment for threatened and endangered species. Prepared by the U.S. Army Corps of Engineers, 170 p. (Available from U.S. Army Corps of Engineers, Walla Walla District, Building 602, City-County Airport, Walla Walla, WA 99362.)

Corps of Engineers, U.S. Army (COE).

1992. 1992 Columbia River salmon flow measures options analysis (OA)/environmental impact statement (EIS). Prepared by the U.S. Army Corps of Engineers, 304 p. (Available from U.S. Army Corps of Engineers, Walla Walla District, Building 602, City-County Airport, Walla Walla, WA 99362. )

Dorband, W. R.

1980. Benthic macroinvertebrate communities in the lower Snake River reservoir system. Ph.D. Dissertation. University of Idaho, Moscow, $172 \mathrm{p}$.

Elliot, D. G., and R. J. Pascho.

1991. Juvenile fish transportation: Impact of bacterial kidney disease on survival of spring/summer chinook stocks. Annual Report-1989 to U.S. Army Corps of Engineers, Contract E86880047, 203 p. (Available from U.S. Army Corps of Engineers, Walla Walla District, Building 602, CityCounty Airport, Walla Walla, WA 99362.)

Elliot, D. G., and R. J. Pascho.

1992. Juvenile fish transportation: impact of bacterial kidney disease on survival of spring/summer chinook salmon stocks, 1990. Annual report to U.S. Army Corps of Engineers, Contract E86890043, 169 p. (Available from U.S. Army Corps of Engineers, Walla Walla District, Building 602, City-County Airport, Walla Walla, WA 99362.)

Fish Passage Center.

1988. Smolt monitoring program. 1987 Annual Report to Bonneville Power Administration, Project 87-127, $112 \mathrm{p}$. (Available from Bonneville Power Administration, Div. of Fish and Wildlife-PJ, P.O. Box 3621, Portland, OR 97208.)

Fish Passage Center.

1991. Fish Passage Center Annual Report 1990 to Bonneville Power Administration, Project 87-127, 77 p. (Available from Bonneville Power Administration, Div. of Fish and Wildlife-PJ, P.O. Box 3621, Portland, OR 97208.) 
Fish Passage Center.

1992. Fish Passage Center Annual Report 1991 to Bonneville Power Administration, Project 87-127, 52 p. (Available from Bonneville Power Administration, Div. of Fish and Wildlife-PJ, P.O. Box 3621, Portland, OR 97208.)

Giorgi, A. E., G. A. Swan, W. S. Zauqq, T. C. Coley, and T. Y. Barila.

1988. Susceptibility of chinook salmon smolts to bypass systems at hydroelectric dams. N. Am. J. Fish. Manage. $8: 25-29$.

Giorqi, A. E., W. D. Muir, W. S. Zaugg, and S. McCutcheon. 1990. Biological manipulation of migration rate: The use of advanced photoperiod to accelerate smoltification in yearling chinook salmon, 1988. Report to Bonneville Power Administration, Contract DE-AI79-88BP50301, 33 p. (Available from Northwest Fisheries Science Center, 2725 Montlake Blvd. E., Seattle, WA 98112-2097.)

Giorgi, A.

1991. Mortality of yearling chinook salmon prior to arrival at Lower Granite Dam on the Snake River. Progress Report to Bonneville Power Administration, Contract DE-AI7991BP16570, 26 p. (Available from Bonneville Power Administration, Div. of Fish and Wildlife-PJ, P.O. Box 3621, Portland, OR 97208.)

Giorqi, A. E., W. D. Muir, W. S. Zaugg, and S. McCutcheon. 1991. Biological manipulation of migration rate: The use of advanced photoperiod to accelerate smoltification in yearling chinook salmon, 1989. Report to Bonneville Power Administration, Contract DE-AI79-88BP50301, 38 p.

(Available from Northwest Fisheries Science Center, 2725 Montlake Blvd. E., Seattle, WA 98112-2097.)

Healy, M. C.

1983. Coastwide distribution and ocean migration patterns of stream- and ocean-type chinook salmon, Oncorhvnchus tshawvtscha. Can. Field-Nat. 97:427-433.

Kiefer, R. B., and K. A. Forster.

1990. Intensive evaluation and monitoring of chinook salmon and steelhead trout production, Crooked River and Upper Salmon River sites. Annual Report to Bonneville Power Administration, Contract DE-BI79-84-BP13381, 75 p.

(Available from Bonneville Power Administration, Div. of Fish and Wildlife-PJ, P.O. Box 3621, Portland, OR 97208.) 
Kindley, R.

1991. The flow/survival/time travel relationship: Review and analysis of supporting information and rationale for flows for juvenile spring and summer chinook migrations. Pacific Northwest Utilities Conference Committee, $35 \mathrm{p}$.

(Available from Pacific Northwest Utilities Conference Committee, One Main Place, 101 S.W. Maine, Suite 810, Portland, OR 97204.)

Matthews, G. M., D. L. Matthews, J. R. Harmon, C. S. McCutcheon, and A. J. Novotny.

1987. Evaluation of transportation of juvenile salmonids and related research on the Columbia and Snake Rivers, 1986. Report to U.S. Army Corps of Engineers, Contract DACW68-84H-0034, 34 p. (Available from Northwest Fisheries Science Center, 2725 Montlake Blvd. E., Seattle, WA 98112-2097.)

Matthews, G. M., J. R. Harmon, S. Achord, 0. W. Johnson, and L. A. Kubin.

1990. Evaluation of transportation of juvenile salmonids and related research on the Columbia and Snake Rivers, 1989. NMFS Research Report to U.S. Army Corps of Engineers, Contract DAW68-84-H0034, 59 p. (Available from Northwest Fisheries Science Center, 2725 Montlake Blvd.'E., Seattle, WA $98112-2097$. )

Matthews, G. M., and R. S. Waples.

1991. Status review for Snake River spring and summer chinook salmon. U.S. Dep. Commer., NOAA Tech. Memo., NMFS F/NWC-200, 75 p.

Matthews, G. M., S. Achord, J. R. Harmon, 0. W. Johnson,

D. M. Marsh, B. P. Sandford, N. N. Paasch, K. W. McIntyre, and

K. L. Thomas.

1992. Evaluation of transportation of juvenile salmonids and related research on the Columbia and Snake Rivers, 1990. NMFS Research Report to U.S. Army Corps of Engineers, Contract DAW68-84-H0034, 57 p. (Available from Northwest Fisheries Science Center, 2725 Montlake Blvd. E., Seattle, WA 98112-2097.)

Maule, A. G., C. B. Schreck, and S. L. Kaattari.

1987. Changes in the immune system of coho salmon (Oncorhvnchus kisutch) during the parr-to-smolt transformation and after implantation of cortisol. Can. $\mathrm{J}$. Fish. Aquat. Sci. 44: 161-166.

Maule, A. G., R. A. Tripp, S. L. Kaattari, and C. B. Schreck. 1989. Stress-induced changes in qlucocorticoids alter immune function and disease resistance in chinook salmon (Oncorhvnchus tshawvtscha). J. Endocrinol. 120:135-142. 
McCormick, S. D., W. W. Dickhoff, J. Duston, R. S. Nishioka, and H. A. Bern.

1991. Developmental differences in the responsiveness of gill $\mathrm{Na}^{\prime}, \mathrm{K}$-ATPase to cortisol in salmonids. Gen. Comp. Endocrinol. 84:308-317.

Miller, W. H., T. C. Coley, H. L. Burqe, and T. T. Kisanuki. 1990. Analysis of salmon and steelhead supplementation: emphasis on unpublished reports and present programs. Part I In W. H. Miller (editor), Analysis of salmon and steelhead supplementation, Parts 1-3. Technical Report 88-100, Bonneville Power Administration, p 1-46.

(Available from Bonneville Power Administration, Div. of Fish and Wildlife-PJ, P.O. Box 3621, Portland, OR 97208.)

Muir, W. D., and R. L. Emmett.

1988. Food habits of migrating salmonid smolts passing Bonneville Dam in the Columbia River, 1984. Regulated Rivers 2:1-10.

Muir, W. D., C. S. McCutcheon, A. E. Giorgi, W. S. Zaugg, W. W. Dickhoff, and B. R. Beckman.

1988. Behavior and physiology studies in relation to yearling chinook guidance at Lower Granite and Little Goose Dams, 1987. NMFS Research Report to U.S. Army Corps of Engineers, Contract DAW68-84-H0034, 47 p. (Available from Northwest Fisheries Science Center, 2725 Montlake Blvd. E., Seattle, WA 98112-2097.)

Muir, W. D., A. E. Giorqi, W. S. Zauqg, S. R. Hirtzel, and B. R. Beckman.

1990. An assessment of the relationship between smolt development and fish guiding efficiency at Lower Granite Dam, 1989. NMFS Research Report to U.S. Army Corps of Engineers, Contract DAW68-84-H0034, 19 p. (Available from Northwest Fisheries Science Center, 2725 Montlake Blvd. E., Seattle, WA 98112-2097.)

Muir, W. D., W. S. Zaugg, C. S. McCutcheon, and J. G. Williams. 1992. Biological manipulation of migration rate: the use of advanced photoperiod to accelerate smoltification in yearling chinook salmon, 1990. Report to Bonneville Power Administration, Contract DE-AI79-88BP50301, 34 p.

(Available from Northwest Fisheries Science Center, 2725 Montlake Blvd. E., Seattle, WA 98112-2097.)

National Marine Fisheries Service.

1991. Endangered and threatened species; proposed threatened status for Snake River spring, summer, and fall chinook salmon. Federal Register 56(124):29542+. 
Park, D. I., G. M. Matthews, J. R. Smith, T. E. Ruehle,

J. R. Harmon, and S. Achord.

1984. Evaluation of transportation of juvenile salmonids and related research on the Columbia and Snake Rivers, 1983. NMFS Research Report to U.S. Army Corps of Engineers, Contract DAW68-78-C-0051, 58 p. (Available from Northwest Fisheries Science Center, 2725 Montlake Blvd. E., Seattle, WA 98112-2097.)

Park, D. L., G. M. Matthews, and T. E. Ruehle.

1986. Evaluation of transportation of juvenile salmonids and related research on the Columbia and Snake Rivers, 1985. NMFS Research Report to U.S. Army Corps of Engineers, Contract DACW68-84-H-0034, 27 p. (Available from Northwest Fisheries Science Center, 2725 Montlake Blvd. E., Seattle, WA 98112-2097.)

Patiño, R., C. B. Schreck, J. L. Banks, and W. S. Zaugg. 1987. Effects of rearing conditions on the developmental physiology of smolting coho salmon. Trans. Am. Fish. Soc. $116: 213-220$.

Petersen, J. H., D. B. Jepsen, R. D. Nelle, R. S. Shively, R. A. Tabor, and T. P. Poe.

1990. System-wide significance of predation on juvenile salmonids in Columbia and Snake River reservoirs. Annual Progress Report to Bonneville Power Administration, Project 90-078, Contract DE-AI79-90BP07096, 53 p. (Available from Bonneville Power Administration, Div. of Fish and WildlifePJ, P.O. Box 3621, Portland, OR 97208.)

Raymond, H.

1979. Effects of dams and impoundments on migrations of juvenile chinook salmon and steelhead from the Snake River, 1966 to 1975. Trans. Am. Fish. Soc. 108(6):505-529.

Raymond, $\mathrm{H}$.

1988. Effects of hydroelectric development and fisheries enhancement on spring and summer chinook salmon in the Columbia River Basin. N. Am. J. Fish. Manage. 8:1-24.

Rondorf, D. W., M. S. Dutchuk, A. S. Kolok, and M. L. Gross. 1985. Bioenerqetics of juvenile salmon during the spring outmigration. Annual Report to Bonneville Power Administration, 78 p. (Available from Bonneville Power Administration, Div. of Fish and Wildlife-PJ, P.O. Box 3621, Portland, OR 97208.) 
Rondorf, D. W., W. R. Nelson, W. H. Miller, and W. P. Conner. 1991. Identify the spawning, rearing, and migratory

requirements of fall chinook salmon in the Columbia River Basin. Statement of Work to Bonneville Power

Administration, 24 p. (Available from Bonneville Power Administration, Div. of Fish and Wildlife-PJ, P.O. Box 3621, Portland, OR 97208.)

Servizi, J.A.

1990. Sublethal effects of dredged sediments on juvenile salmon. In C. A. Simenstad (editor), Effects of dredging on anadromous Pacific coast fishes: Workshop proceedings, Seattle, WA, September 8-9, 1988. Univ. Wash., p. 57-63.

Shively, R. S., R. A. Tabor, R. D. Nelle, D. B. Jepsen, J. H. Petersen, S. T. Sauter, and T. P. Poe.

1991. System-wide significance of predation on juvenile salmonids in Columbia and Snake River reservoirs. Annual Progress Report to Bonneville Power Administration, Contract DE-AI79-90BP07096, 56 p. (Available from Bonneville Power Administration, Div. of Fish and WildlifePJ, P.O. Box 3621, Portland, OR 97208.)

Sigler, J. W., T. C. Bjornn, and F. H. Everest.

1984. Effects of chronic turbidity on density and growth of steelheads and coho salmon. Trans. Am. Fish. Soc. 113:142150 .

Sigler, J. W.

1990. Effects of chronic turbidity on anadromous salmonids: Recent studies and assessment techniques perspective. In C. A. Simenstad (editor), Effects of dredging on anadromous Pacific coast fishes: Workshop proceedings, Seattle, WA, September 8-9, 1988. Univ. Wash., p 26-37.

Sims, C. A., and F. Ossiander.

1981. Migrations of juvenile salmon and steelhead trout in the Snake River from 1973 to 1979. NMFS Report to U.S. Army Corps of Engineers, Contract DACW68-78-C-0038, 31 p. (Available from Northwest Fisheries Science Center, 2725 Montlake Blvd. E., Seattle, WA 98112-2097.)

Skalski, J. R., and A. E. Giorqi.

1992. Juvenile passage proposal: Estimating smolt travel time and survival in the Snake and Columbia Rivers. Prepared for Bonneville Power Administration, $55 \mathrm{p}$. (Available from Bonneville Power Administration, Div. of Fish and Wildlife-PJ, P.O. Box 3621, Portland, OR 97208.) 
Solomon, D. J.

1978. Migration of smolts of Atlantic salmon (Salmo salar

L.) and seatrout (Salmo trutta $L$. ) in a chalkstream. Env.

Biol. Fishes 3:223-229.

Steward, C. R., and T. C. Bjornn.

1990. Supplementation of salmon and steelhead stocks with hatchery fish: A synthesis of published literature.

Part 2 In W. W. Miller (editor), Analysis of salmon and steelhead supplementation, Parts 1-3. Report to Bonneville Power Administration, Project 88-100, p. 1-126. (Available from Bonneville Power Administration, Div. of Fish and Wildlife-PJ, P.O. Box 3621, Portland, OR 97208.)

Thorne, R. E., C. J. McClain, J. Hedqepeth, E. S. Kuehl, and J. Thorne.

1992. Hydroacoustic surveys of the distribution and abundance of fish in Lower Granite Reservoir, 1989-1990. Final Report to U.S. Army Corps of Engineers, Contract DAW68-C-0022, 96 p. (Available from U.S. Army Corps of Engineers, Walla Walla District, Building 602, City-County Airport, Walla Walla, WA 99362.)

Vigg, S., and C. C. Burley.

1990. Developing a predation index and evaluating ways to reduce salmonid losses to predation in the Columbia River. Report A In A. A. Niqro (editor), Developing a predation index and evaluating ways to reduce salmonid losses to predation in the Columbia River Basin. Annual Report, August 1988-September 1990, to Bonneville Power Administration, Contract DE-AI79-88BP92122, p 6-78. (Available from Bonneville Power Administration, Div. of Fish and Wildlife-PJ, P.O. Box 3621, Portland, OR 97208.)

Ward, D. L., M. P. Zimmerman, R. M. Parker, and S. S. Smith. 1993. Development of a system-wide predator control program: Indexing, fisheries evaluation, and harvest technology development. In C. F. Willis and A. A. Nigro (editors), Development of a system-wide predator control program: Stepwise implementation of a predation index, predator control fisheries, and evaluation plan in the Columbia River Basin. Annual report 1991 to Bonneville Power Administration, Contract DE-BI79-90BP07084, p 343-434. (Available from Bonneville Power Administration, Div. of Fish and Wildlife-PJ, P.O. Box 3621, Portland, OR 97208.) 
Welsh, T. L.

1988. Development of chinook salmon fry outplanting strategies for supplementation of depressed stocks and evaluation of Johnson Creek fish passage improvement projects. Part II In C. E. Petrosky, T. B. Holubetz, and L. B. Everson (editors), Idaho habitat evaluation for offsite mitigation record. Annual Report (1987) to Bonneville Power Administration, Contract DE-A179-84BP13381, 42 p. (Available from Bonneville Power Administration, Div. of Fish and Wildlife-PJ, P.O. Box 3621, Portland, OR 97208.)

Yamauchi, K., M. Ban, N. Kasahara, T. Izumi, H. Kojima, and T. Harako.

1985. Physiological and behavioral changes occurring during smoltification in the masu salmon, Oncorhvnchus masou. Aquaculture 45:227-235.

Zaugg, W. S., E. F. Prentice, and F. W. Waknitz.

1985. Importance of river migration to the development of seawater tolerance in Columbia River anadromous salmonids. Aquaculture 51:33-47.

Zauqg, W. S., W. W. Dickhoff, B. R. Beckman, C. V. W. Mahnken. G. A. Winans, T. W. Newcomb, C. B. Schreck, A. N. Palmisano, R. M. Schrock, G. A. Wedemeyer, R. D. Ewing, and C. W. Hopley. 1991. Smolt quality assessment of spring chinook salmon. Annual Report to Bonneville Power Administration, Contract DE-AI79-89BP97300, 109 p. (Available from Northwest Fisheries Science Center, 2725 Montlake Blvd. E., Seattle, WA 98112-2097.) 


\section{LIST OF CONTRIBUTORS}

Roy Beaty, Columbia River Inter-tribal Fish Commission.

David Bennett, University of Idaho.

Timothy Fisher, Bonneville Power Administration.

Albert Giorgi, Don Chapman Consultants.

Robert Iwamoto, National Marine Fisheries Service

Alec Maule, United States Fish and Wildlife Service.

William Muir, National Marine Fisheries Service.

Cleveland Steward, Mobrand Biometrics.

John Williams, National Marine Fisheries Service. 
APPENDIX

\section{Comment Letters}

A draft of this Research Plan was sent to the following members of the Fish Passage Advisory Committee (FPAC) in September, 1992 for review and comment:

James Nielsen, Washington Department of Wildlife

Ronald Woodin, Washington Department of Fisheries

Craig Tuss, U.S. Fish and Wildlife Service

Ronald Boyce, Oregon Department of Fish and Wildlife

Christopher Ross, National Marine Fisheries Service

Steven Pettit, Idaho Department of Fish and Game

Margaret Filardo, Fish Passage Center

Robert Heinith, Columbia River Inter-tribal Fish Commission.

Formal comments were received from the following:

Craig Tuss, U.S. Fish and Wildlife Service

Ronald Boyce, Oregon Department of Fish and Wildlife

Christopher Ross, National Marine Fisheries Service

Robert Heinith, Columbia River Inter-tribal Fish Commission.

All comments received were considered and the text was revised where appropriate. The comment letters received follow. 
MeMORANOUM

TO: MARCARET IIINRO, TRC

TROM: BOB HeINITH, cricte

DATE: DKCARER 23, :992

R.: COLATITB ON REBRARCA LASN TO DETERMINE TIMING, LOCXTION, MONITUDE, AND CNDSY OS MORTATITY TOR MITD AND HATCHERY SPRING/SUMAR CHIAOOX SAIMON SMOLTS ABOVE LOWRR GRANITE DAM

\section{General Commonts}

There is coridezable confusica in the plan as $=0$ crganization. Is the plan part of an entire srogram as aijucea to ca pago i?, "?=ogram Goal"? It 90, how does the program zolate t) the =esearch plan?

Envifonmental isfuer:ses on ifid ahisook froduction ard mertaliey should be the top priority of the plan. A thosough comprison betwees historical physical habitat characteristics of the Snake sasin above Lower Granito Dam, asd extant prysical hacitat characteristics, and their solationship to dhisook freshwater 115e histories and mortalisy is essential to identify snvironmental i.pacts as deseribed by Petto (1980), oxsboxs (1990), Hoedo and Rinre (1990) and CRITFC (I991). Witr respect to providiag tho necessazy itte arure review on historical physicad habirnt characturibcics, =ho plan lacks much dotai.. with rospect 0 rosearch icientifying extane physical habitat hharacteristics, the plan jacks it thozough systematic approach.

Physical habitnt characteristics which should be identified and evuluated include a hiveorica: hydrolcgio and hydraliis jeoretry analysis ys described $a$ orsboza (2990) and imesmas and Orabora (1987), a through waedr quality asalysis inelieisg identificaeion of incrganil uni oxgunis compcnents, and a gimary

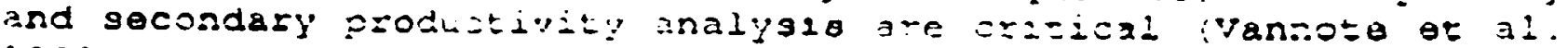
1930; Naters 19691 .

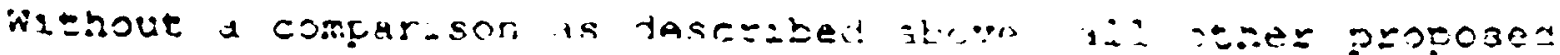

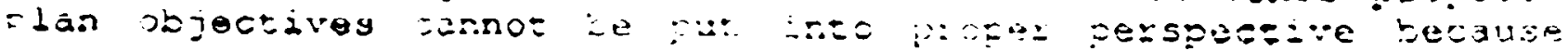
T.

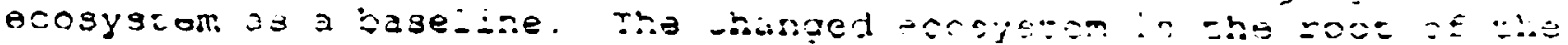

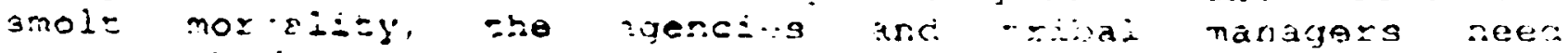

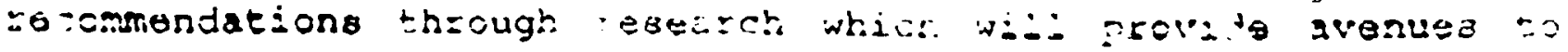

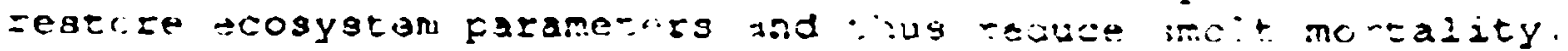


Page a Meir:=L Commerta cn LGMS Pegearch Plan

Recomnonded Research ExiOritie日

- Defina critical phyarcal habitat sharactoristico which ímit chinook production and survival in the snake Basin above Lone:

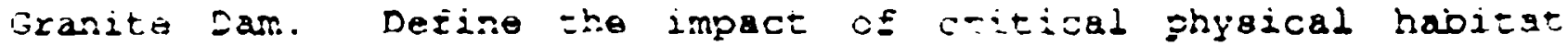
paramezers on primary and secondary producticn. This can be accompiighed by a very thorough i iterature review including work done in other balns, an research comparirg river reaches above the Lower Sanite 2 roject, and withil the lower Grarite 2 roject.

2. Conduct a comprchensivo snake Basin hatchery roviow to identify causative factors related to large nortalities of hacctery Is beforo they reach jower Granite Jam. Include a review of operations, broodstock collection and propagation technigies, diseare histories, zotter definitiong of stoch diffezences, uspecialiy related to habieat zequirements, and the ratiral capacity of the basin to rear juveniles at different i ife histony stages a noted in ichacowich and McIntyre (1987).

3. Estimate the survival and travel time for wils and hatchery yearling salmon smoltg along tho migration corridor ising pit tags. wild smolts should be given priority. Coordination with existing programa ahould be priozity.

6. Conduct eisheries impact studieg for wild and hatchery fist. with priority given to wild fish. Corcertzate on gaining precise and accurate maaurement of parameters which have a serorg infiuence on survival such 20 time and sizo at an importart ij histoxy stage at selected reaches of the basin. Ifchatorict ans cramer (2979) showed meseurement of survival and abusdance are ioss seatioticaliy sensitive to change than moasurements of tirae ard size at important life histcry stages. Without thig approach. rosearch to idontify changes will be trying to focus in on a movisg target.

\section{Dehe: Commer:s}

There is an absence of critinal evaluatior. of past resoarch in. the background gections le cbzectira 2 inder Experimenta:

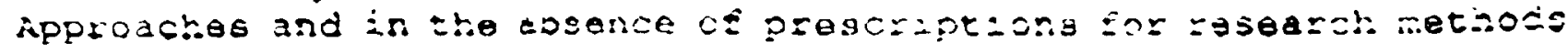
and for a resiaren review ar.e approya yzosess. 
mo intrediate problam is that $\vdots=23$ :ot known tow tei- wild

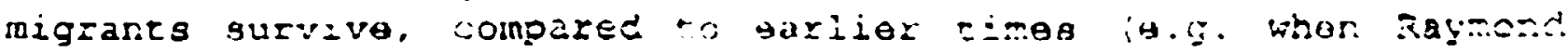
coliected his data or bofcze thorl. Tha zremise that yoarliag

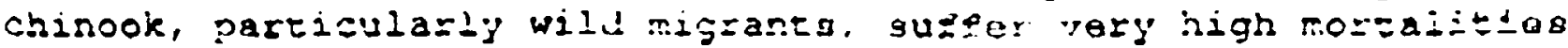
dur:ag migratior to Lower Grar:te far is not weil supported in the slas. The extert of overwinter mortality is not well docureatid in tho plas.

specific nethods preacribed as research prioritios in the plar. (e.g. simultaneous roleases of eIr-taggod smolts is ijEferent reservoir locattons) appear to savor fare:cular seudy desagns that heve not been critically reviawed and sancticned by the stoerisg comaitteo.

The NMES survival study Eroposal (Ifamoto and Skaiski) was not

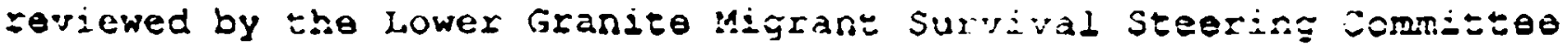
prior to subrittal to 3PA, nor has =he comniteee sancisoned the NMrs's proposal. merefore, the miss proposal should bo considezed indepandent of this plas. 


\section{NRAFT}

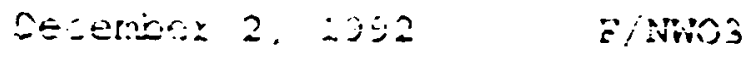

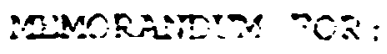

SROM:

SUBJECM:

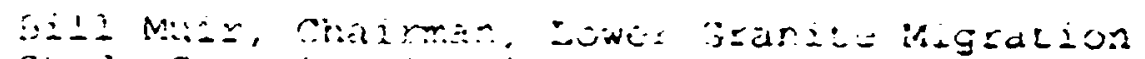
SEUAY Stedrig:G Commizlee

Chris V. Ress mes

Reriew of the "pesearch oiar to deremane ining, iscation, magrieuge anc cause of

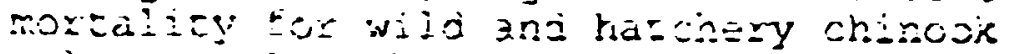
salnon sincits abue uciver Brantce Dam."

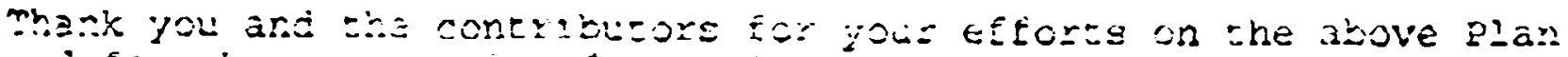

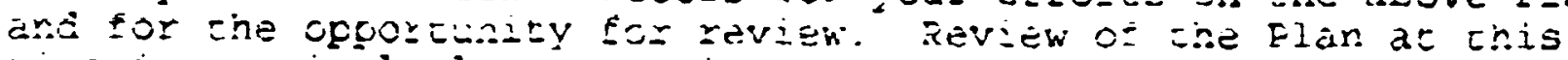
z-TE

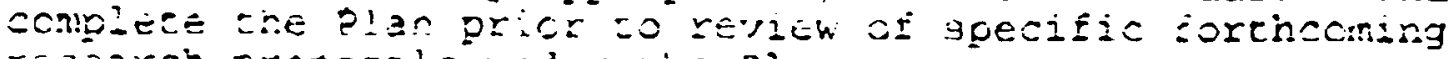
zesearch groposals unds crie Eian.

The revlews and aporoachis are intomatuve and weli jo:e. rîe

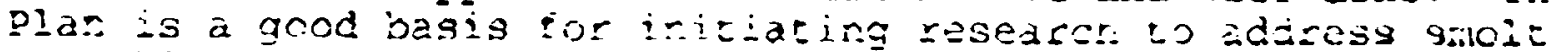

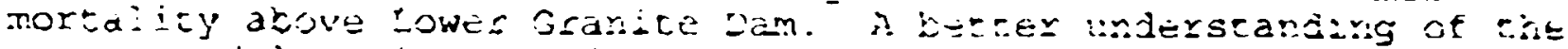

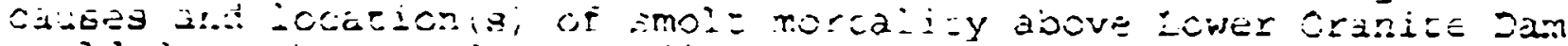

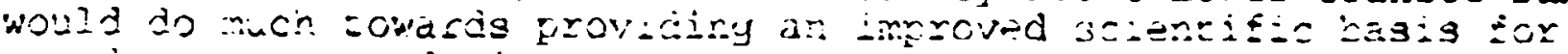
sound nanagement cieaigions.

?ร. : i: para. z.

The Eirst cibjective ories iscacior. of moreality as are of the objective, witial: is clearyy indicazed ir: the jajy of the reopre. lociation sinould be inciludec.

Po. 22, paza. 2. İ is uncíar what estinares oe sumsival are be ing refirred to here - tor example. relative recovery zares oz vough suzrivi estimates based on assuned coilection efficiencieg?

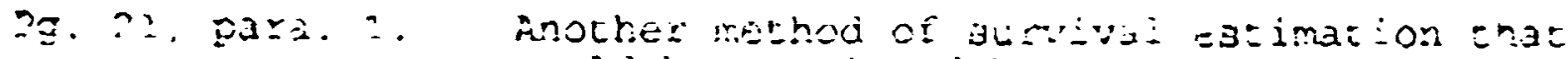

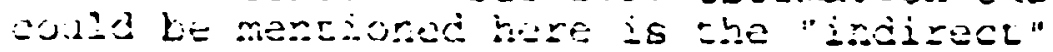

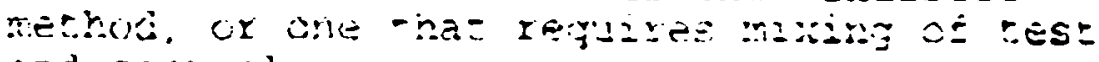
ard controla.

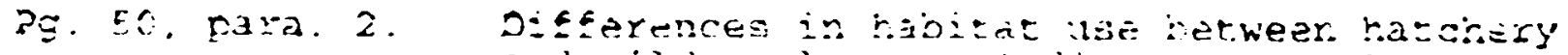
arit wild omolte injy tidicate sor oniy ror:-

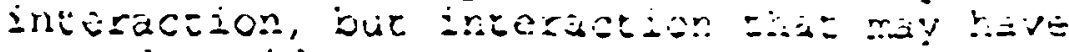
caised ibidzrosis. 


\section{Unegor}

MEMORANDUM

$\therefore: \cdots: B: ?$

FISH AND

WILDLIFE

Date: $\quad$ November 17, 1992

To: $\quad$ Bill Muir (NMFS-Cook)

From: R. Boyce ₹o

Re: $\quad$ Comments on "Research Plan to determine the timing, location, magnitude, and cause of mortality for wild and hatchery chinook smolts above Lower Granite Dam"

I have reviewed the referenced document and am pro-riding these comments for your consideration.

It is unclear to me what type of comments you are soliciting at this point of Research Plan development. I was under the impression that the LGMS steering Committee would be providing detailed proposals including experimental designs for comment. Instead, the plan is a document that identifies research needs and develops alternatives and recommendations for developing research proposals. My original understanding was that the Phase I product from the steeringlommittee would be an experimental protocol for addressing the two program objectives.

It appears therefore that you are probably asking for direction on the research priority recommendations provided on Page 53 and that is what I provide below.

1. Research Priorities 1 and 2 are the highest priorities to pursue in 1993. I would defer Priorities 3-5 until we have an understandrng of the magnitude of losses.

2. I am not convinced that it is necessary at the onset to make absolute estimates of survival to determine if losses are occuringand to identify causative factors. As your agency knows best, the prospect of PIT tagging large numbers of additional Wild spring/summer chinook in the snake is bleak under ESA. I suggest that the LGMS attempt to design studies utilizing existing marking programs to assess the relative recovery rates of wild and hatchery spring/summer chinook to Lower Granite. assessment of the relative recovery rate of wilci and hatchery spring/summer chinook to Lower Granite would provide an 
indication of relative mortalities of these fish. If losses are indicated by these studies, more in-depth studies can be designed to determine location (tributary, upper, mid- and lower reservoir) and cause of mortality.

3. The study needs to be closely coordinated with similiar studies in the Snake River, ie studies being conducted under LSRCP. The NPT is conducting migration studies of wild and hatchery spring chinook in the Imnaha River. And, ODFW has been discussing a study that would involve serial releases of hatchery spring chinook in the Grande Ronde to determine effect of release location on survival.

4. FPAC need to discuss the appropriateness of using BPA funds for future work by the steering Committee and the planned Coordinator under LGMS. The steering Committee has drafted a plan that should guide proposal development of migrational/survival studies of Snake River wild spring/summer chinook. I understand that this subject will be further discussed at FPAC today.

C: FPAC

Young, Nigro, Beamesderfer, 


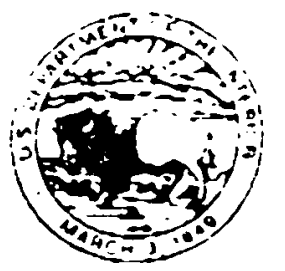

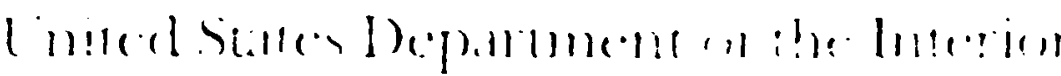

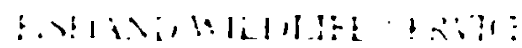

$$
\begin{aligned}
& \text { Otfice of Colsmb:a Ru er Coordiritor } \\
& \text { 93:7 Highuay 99. Sulic } A \\
& \text { Varicosver. Hashingion } 98665
\end{aligned}
$$

MEMORANDUM

November 16, 1992

TO: Bill Muir

FROM: Craig Tuss

SUBJECT: Review sf "Research Plan I0 determine timing, location, magnitude and cause of morkalty foz wild and hatchery smolts above Louer Grante Dam"

Thank you for the opportunity to review and comment on this document. In genera' the research plan is very well done. I do have some concerns with hou the stated objectives are addressed from this point.

The plan should provide some prionity for the sued objectives. If the current plan tras used by a group proposing work there would be no direction away versus what should be accomplished secondarily. This plan should not be an open encied vehicle for funding. Again. a priority on the objectives would go a long way toward tightening up the document and making it a useful plan for future work.

An example of this problem is the recendy received proposal by Drs. John Williams and Johr: Skalski. The plan has not even been revieued and we are already being askad to review work to address the plan's objectives.

I think some of this concern and confusion comes from a misunderstanding as to the very fulure of projest 91-017. Some agencies may think 91-017 will continje while oihers see 91-017 coming 10 an end and other specific proposals conducted to address the specinic objectives of the research plari.

Please call me if you have questions.

cc: FPAC

Alec Maule; Bill Neison, NFRC CRFS

Wally Steucke, CBFWA 